STATE OF ALASIA

William A. Egan - Governor

DEPARTMENT OF NATURAL RESOURCES

Phil R. Holdsworth - Commissionex

DIVISION OF MINES AND MINERALS

James A. Williams - Director

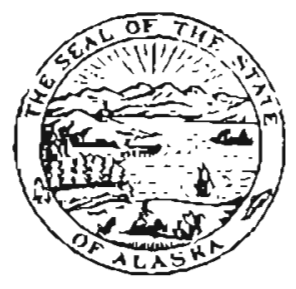

GEOLOGIC REPORT NO. 13

Geologica1 and Geochemical Investigations Near Paxson, Northern Copper River Basin, Alaska

By

A. W. Rose and

R. H. Saunders

Juneau, Alaska

June, 1965

isorinte-: June $1 \geqslant 70$ 
Introduction

Volcanic and Sedimentary Rocks

Pre-Triassic Greenschist and Amihibolite (ga)

Pre-Triassic(?) Greenstone and Andesite (g)

Permian(?) Slate, Quartzite, Rhyolite and Anaesite (Ds,Pv)

Triassic Anchitheatre Basalt (TRa)

pleistocene and Recent Deposits

Intrusive Rocks

Gabbro. Diorite and Quartz Diorite in the Meier and

Twelvemile Creek Areas ( $\left.A_{1}, A_{2}\right)$

Hornblende Andesite and Coarse Gabioro in the Passon

Mountain Area ( $\left.B_{1}, B_{2}\right)$

Gabbro and Diorite of the Amrhitheatre Mountains (C)

Gabbro, Diorite and Granooiorite of Flat Tof Mountain

$\left(D_{1}, D_{2}, D_{3}, D_{4}\right)$

Leucocratic Biotite Granodiorite at leier and Hogan Hill (E)

Intrusive Basalt, Andesite anó Dacite of Flat ToE

liountain (E)

Sitructure

iiconomic Geology

Paxson Mountain Area

Irocality 1

Locality 2

Localicy 3

Locality 4

Locality 5

Locality 6

Locality 7

Locality 8

Locality 9

Locality 10

Other Corcer Occurrences in the Daxson Area

Origin of Correr in the Farson lountain Area

Areas South of Parson Lake

Geochemical Data

Summary

Suggestions for Prospecting

Bibliography

8
8
10

ILLUSTRATIONS

Table 1 Mineralogical Composition of Intrusive Rocks

Table 2 Geochemical Data on Stream Sediments 


\section{ILLUSTRATIONS (CONtinuea)}

Figure 1 Index Map and Generalized Geology of the Paxson Area 24

Legend for Figure 2 Through $9 \quad 25$

Figure 2 Hogan Hill Area 26

$\begin{array}{ll}\text { Eigure } 3 \text { Meier Area } & 27\end{array}$

$\begin{array}{lr}\text { Figure } 4 \text { Twelvemile Creek Area } & 28\end{array}$

Figure 5 Flat Top Mountain Area 29

Figure 6 Southern Paxson Mountain and Vicinity 30

Figure 7 Paxson Mountain and Fish Creek 31

Figure 8 Northern Paxson Mountain and Vicinity 32

Figure 9 Amphitheatre Mountains 33

Eigure 10 Sketch of Hillside at Locality $3 \quad 34$

Figure 11 Map of Locality 10 - Paxson Mountain Area 35 


\title{
GEOLOGICAL AND GEOCHEMICAL INVESTIGATIONS NEAR PAXSON, NORTHERN COPPER RIVER BASIN, ALASKA
}

By Arthur W. Rose and Robert $H$. Saunders

\author{
INTRODUCTION
}

The area covered by this report is in southcentral Alaska along the Richardson and Denali Highways, which join at Paxson (figure 1). Interest in the area was generated by two coppex showings near Paxson and others to the west in similar lithology, plus several granitic intrusives south and southwest of Paxson. The purpose of this project was to visit and describe the known copper showings, map the geology of the area surrounding the showings and the granitic intrusives, and collect stream seaiment samples for geochemical analysis from as much of the requon as cossiale.

The mapping and sampling were carried out mailiy during June and July 1964 by the writers assisted by walter Phillips. Mr. Saunders is responsible for stream sediment sampling in the Amphitheatre Mountains northwest of the Denali Kighway, along the Richardson Highway, and in the western part of the Twelvemile Creek drainage. Most of the remaining stream sediment sampling was done by Phillips. Gordon Herreic, geologist, and assistant Michael Mitahell spent three days mapping and sampling in the leier area along with Rose and Phillips.

Rock outcrops are very poor up to an elevation of about 3500 feet, the upper limit of thick brusi cover. Above 3500 Eeet, outcrops, talus, and frost-riven blocks close to outcrop are relatively abundant, but an almost complete cover of lichens obscures the character of the rocks ano structural relationsinips. so that very few determinations of contact relations, attitudes and other structures and textures have been made.

Previous geologic work in the area has been done by Moffit (1912, 1954). He recognized three geologic units in the area. A unit of greenston schist, and limestone, plus basic and dioritic intrusives, was mapped extending westward from the south end of Paxson Lake. An age of Carbonifero or older was assigned to these rocks. The second unit of "amygdaloidal lava flows, diabase, and basalt," also trending east-west, was shown passing through the north end of $P$ axson Lake and the south end of Sumit Lake. Thes rocks were tentatively assigned to the Permian and Triassic. Mis thira unit consisted of granitic intrusives of Mesozoic age, one in the Meier area and another on Flat Top Mountain. 
Ančreason and others (1964), in a report on an aeromagnetic and gravity jurrey oi the Copper River Basin, recognize the same geologic units as Moffi ana show a few additional outcrors. The magnetic maf clearly shows the east yest trend of the rocks vest of the Richardson Highway and suggests that zeijtively ronmagnetic rocks (sediment?) are present between the bands of mooerately to highly magnetic greenstone that are exposed in the Meier and rogan Hill areas.

\section{VOLCANIC AND SEDIMENTARY ROCKS}

Erc-Triassic greenschist and anphibolite (ga)

This grou: incluoes much of the Carboniferous (?) greenstone, schist, anc Iimestone unit of voffit $(1954)$. Exposures of this group were mapped in the vier. Hogan Hill ano Thelvemile Creek areas (figures 2, 3, and 4). The roci: is tyrically. meöiun to aarl: rreen or grayish green, anö has fair to goo zclizion. Most srecimens are fine-grained, but a few are medium-grained. In the :leier area, nost e:rosures consist of greenschists, composed mainly aliziee, chlorite, erioote ano calcite along with minor quartz and sphene. Fmibolites or oridote amribolites are exrosed in the Hogan Hill and Twelv wile Crcek areas. These rocks contain sodic andesine and green hornblende along with minor anounts of ericiote, carbonate, guartz, chlorite, magnetite, and whene. In the Hogan Hill ano ileier areas, a few vesicular zones are visible in the rocks, and in all three areas, the composition and massive natlirs of mos: c:mosures indicatez that the parent rocks were mainly mafic volcanic flows, although some sills and dikes may be sresent. However, gray wacle is Lresent in cuccro:s on the highway near Meier, ano thin quartzite bed $=$ yere zeen near ileier and on Hogan Hill. Thinly interbanded light-color carsonate-rich rocks anö jark-colo:sd hornblonoe-rich rock vere seen iocally or Hcgan Hill. The;ie bandec rock:., winich may have originatej as limy tuffs. ccntain abunciant magnetite.

The greenzchist and amihibolite are exosed mainly in areas of high magnetic intenzity on the aeromagnetic man of Andreason et al (1964). lagnetite is :rasent in all the greenschist anj amrhibolite srecimens. makin these rocks a reasonable source for the beltlike sositive magnetic anomalies The minor arounts ces sediments founc in this study are consistent with the suggestion of inareason et al (1964) that nonmagnetic seciments are zresent in at least sone of the intervening covered zones of low magnetic intensity. Hovever, granitic to oioritic igneous rocke may also be responsible for some of the magnetic lows.

The age of the rarent roclis of the greenschist and amphibolite remains uncortain. The lithology bears come similarity to andesitic volcanics, gray yacles, and imsure limestones of lississiprian and Pennsylvanian age describ by Hanson (1963) in the Alaska Range, but this correlation must be considere seculative, as is the age of metamorrhism. 
Pre-Triassic(?) greenstone and andesite (g)

A variety of fine- to medium-grained mafic igneous rocks form the countr rock in the northern part of the Meier area, and possibly on the northern sid of Thelvemile Creek in the Flat Ton Mountain area (figures 3, 4, and 5). These rocks differ from the greenschist and amphibolite mainly by a lack of foliation, or by weak foliation. They also tend to be coarser-grained than the greenschist ano amshibolite, although exceptions are not uncommon. The most common variety is a dark green to gray-green rock that contains a few percent plagioclase phenocrysts as much as $2 \mathrm{~mm}$ in diameter in a matrix of fine-grained (less than $0.5 \mathrm{~mm}$ ) plagioclase and mafic minerals. The proportion of mafic minerals is typically a third to a half. Some specimens axe altered to chlorite, epidote, actinolite, albite, and carbonate, but others are apparently unaltered. The origin of these rocks is not clear. No vesicles, flow tofs or other indications of an extrusive origin were seen, but the grain size is finer than normal plutonic rocks. Possibly both thick flows and hypabyssal intrusives are Eresent. In several exposures, these rocks have been intruded by coarser, lighter-colored diorite (group A).

An exposure of dacite porphyry with an aphanitic green groundmass was found east of Meier. The dacite porchyry is included with this group because of its location with other rocks of the group, but may belong with the basalt. andesite, and dacite intrusives of Flat Top Mountain.

The age of the greenstone and andesite is not clear. They may be (1) fart of the greenschist-amphibolite sequence that has undergone less intense metamorphism, (2) a post-metamorphic but pre-Triassic group of extrusives and shallow intrusives, or (3) a basal fart of the Amphitheatre basalt described below.

Permian(?) slate, quartzite, rhyolite and andesite (PS, PV)

Weakly to moojerately foliated slate, guartzite, rhyolite, andesite, and minor limestone are exsosed on Fish Creeli below Lower Fish Lake (figure 7). These rocks are intruded by a variety of andesite or basalt dikes, and are overlain with aprarent conformity by Amohitheatre basalt flows of Triassic age.

The lowest rocks of this group are exposed in a small gully on the north side of Fish Creek. They consist of south-dipping guartzite, sandstone and minor limestone. The arenaceous rocks are considerably iron-stained and sericitized. and as a result the characteristics of the parent rock are not very clear. One limonite-stained shear zone about 10 feet wide was noted in this interval, and it seems likely that an intrusive body is present nearby. In the lower fart of the gully and on the opfosite slofe of Fish Creek, a thick sequence of black slaty argillite and slate is exposed. Abundant fine pyrite is present in some of the slate, and several mafic dikes were seen. least 2000 feet of slate is present. 
About $1 / 3$ mile south of $E$ ish creek, a unit of southerly-difing weaklyfoliated chloritized rhyolite and massive dark andesite are exposed in a small drainage and in the flat areas at the head of the drainage. Foliation and banding. in these rocks are parallel to the attitude of the underlying slate. Near the top of the volcanics is a zone about 50 feet thick of thinbedded limestone, separated from the volcanics by a diorite sill.

The rocks of this grouf are tentatively considered as Permian, based mainly on correlation of the black slate with similar black shales in the Permian Mankomen formation (Mendenhall, 1905, Rose, 1965), plus the stratigraphic relation to mafic flows terteively considered as Triassic. However, the rocks in question could also be a basal part of the Triassic sequence, or an older fart of the Paleozoic.

Triassic Amphitheatre basalt (TRa)

An east-west belt of weakly altered mafic volcanic rocks plus minor amounts of other rock types forms most of the Amphitheatre Mountains in the northwestern part of the Cofper River Basin (Moffit, 1912, Chapin. 1918). This belt of volcanics is known to extend from the Gakona River westward to the Susitna River, a distance of nearly 100 miles, and the rocks may be fresent farther to the east. The name Amchitheatre basalt is here used for this group of rocks. They have previously been described as "undifferentiat, amygdaloidal lava flows, diabase and basalt, with intercalated tuffaceous an shaly beds" (Moffit, 1954).

In the area mapred, the Amphitheatre basalt is exposed on Paxson Mounta. and on hills to the east, northeast, and northwest (figures 6, 7, and 8). I was also examined in the southern fart of the Rainy Creek area about 20 mile. north of Paxson Mountain (Rose, 1965). The rock in the paxson area is mostl: a dark green massive fine-grained basalt containing a few rlagioclase phenocrysts. Some of the basalt contains hornblende phenocrysts. Sparse vesicles and amygaules composed of epidote, chlorite, calcite, and other minerals are present in many localities. Vesicular zones, some of which are rediish-brown in color, are presumed to be flow toss and are most abundant on the north and northwestern sides of Paxson Mountain. Although individual units are rarely discernible, most of the basalt is believed to occur as flows. Some flow-breccias and agglomerates, as well as shallow intrusives, are also probably gresent but the complete coating of lichens on outcrops makes distinctions of this tyse very difficult. No sedimentary units were found.

In thin section, the least altered specimens consist of porphyritic basalt comrosed of sparse plagioclase phenocrysts in a matrix of plagioclase and augite with an intergranular texture. In all specimens examined microscopically, the plagioclase is albite, even when the augite is completely unaltered. Most samples contain moderate amounts of eoidote and variable 
anounis of calcite which may have formed from calcium releasec by albitizatio. Chlorite is the most comon mineral in the amyooules, but calcice, epidote, and quartz were also noted. In the more highly altered samsles, the augite is a].tered to actinolite, chlorite, and/or epidote. A few patches of chlorit. may have developed from olivine.

The stratigraphic relations and cetrograpicic character of the Amphitheatre basalt suggest Triassic age. In the Valdez Creek area (Ross, 1933), the basalt is overlain by Triassic sediments ano contains interbedded limestone with Triassic fossils. Near the mouth of Eureka creek the basalt overlies Permian rocks (Rose, 2965), and as mentioned freviously, it also overlies presumed Permian rocks on Fish Creek. The petrography is very simil to the Nikolai greenstone on the southern side of the virangell ilountains (Moffit, 1938, Mackevett, 1964a), where a Triassic age has been demonstrated. Assuming that the few attitudes obtained are representative, the basalt is at least 2000 feet thick on the northeast side of Paxson Mountain. Sections of 3500 feet and rore have been reported in other areas (Chapin, 1918).

Pleistocene and Recent deposits.

Several hundred feet of gravel and sand of fresumed pleistocene age are exposed along Paxson, Surmit, and Fielding Lakes and on the Gulkana River above Paxson. Superficial examination suggests that this gravel originated as outwash from glaciers in the Alaska Range during the late Pleistocene. Glacial drift covers much of the lower farts of the area. In general. outcrops on the lower hills are restricted to the northern or northeastern sides of the hills, with drift cover elsewnere. A discussion of the Pleistocene history of the area is given by Pewe (1961).

\section{INTRUSIVE ROCKS}

Gabbro, diorite, and quartz diorite in the Meier and Twelvemile Creek Areas (AI, A2)

Medium-grained diorite and quartz öiorite (Al) are present in the Meier area and on the north side of Twelvemile Creek (figures 3 and 4). Sample $4 A R 38$ (Table 1) is typical of these rocks. Augite is the cominant mafic mineral in most samples, but hornblende appears to be common in some. In the Meier areas, the diorite is clearly intrusive into greenschist and greenstone North of Twelvemile creek. the relations are less clear. Dikes of andesite (group F?) cut the diorite, but andesite (unit g?) also occurs as inclusions in the medium-grained oiorite. The large exposure of andesite west of the diorite is tentatively considered to be older than the diorite, but the contacts between the two rocks could not be interpreted rith certainty, and this andesite may be zart of intrusive group $F$. 
Coarse-grained to fegmaticic diorite or gabbro ( $A_{2}$ ) is crasent in the Meier area, and some of the diorite rorth of Twelvemiie Creek is locally coarse-grained or has diabasic texture similar to the coarse diorite. The most extensive outcrops of this rock type are on the ridge a mile or two north-west of Meier Lake. The coarse-grained diorite is composed of euhedral tablets of plagioclase separated by hornblende, or in some cases, coarse euhedral prisms of hormblende and subhedral plagioclase separated by coarse interstital grains of hornblende and plagioclage. In the specimen examined in thin section (4H16), plagioclase is altered to albite and epidote, and the hornblende is partly altered to actinolite. The stumpy outline of the hornblende suggests that it may have aeveloped from augite, but no trace of augite can be seen. The coarse-grained diorite intrudes both greenschist (ga and unfoliated andesite (g) near Meier. The coarse-grained diorite is not foliated, except in a few outcrops adjacent to the gneissic granodiorite at Meier. The foliation in this locality is believed to be the result of local deformation of the country rock by intrusion of the granodiorite.

The gabbro, diorite, and quartz diorite are similar to gabbro and diorite in the Amphitheatre lountains (group C) and may have a Triassic or later age. If this tentative correlation is incorrect, group $A$ may be Devonian to Triassic in age as suggested by Moffit (1954).

Hornblende andesite and coarse gabhro in the Paxson Mountain area (Bl, B2)

Two small plugs of coarse-grained gabbro ( $B_{1}$ ) were found on Paxson Mountain. A thin section shows coarse augite and albite, along with small amounts of various alteration products.

Numerous narrow (1-10 feet wide) dikes of light-colored andesite $\left(B_{2}\right)$ containing long frismatic crystals of hornblende were mapped on Paxson Mounta (figure 7 and 8 ). A thin section of the andesite discloses about $10 \%$ hornblende in a matrix of fine lath-shaped plagioclase accompanied by $5 \%$ quartz.

The gabbro is considered as an intrusive phase of the Amphitheatre basal and the andesite may be a relatively leucocratic differentiate.

Gabbro and diorite of the Amphitheatre lountains (C)

The upper fart of the hill northwest of Mile 8 on the Denali Highway and south of Fielding Lake is composed of gabbro and diorite of variable texture and composition (figure 8). The typical rock is medium-grained and medium gray in color. Crystals of glagioclase and augite are visible, in some cases with a diabasic texture but usually with granitic texture. Sample $4 A R 174$ in Table 1 gives the mineralogical composition of a relatively dark phase of this intrusive. The color index ranges from about 40 to 60 . In addition, pieces of mafic-rich gabbro or pyroxenite containing small amounts 
of chalcopyrite were found as float on the southeast sice of the hill, but could not be founa in flace ana may have been carriea in by glaciers from t\} north. However, Moffit (1912) recorts peridotite "in tre Tangle Lakes vicinity".

The gabbro and diorite are ciearly Triassic or younger, and are tentatively considered as slutonic representatives of the same magmatic episode that formed the Triassic Amphitheatra: basalt flows.

Gabbro, diorite ano granodiorite of Flat Top Mountain $\left(D_{1}, D_{2}, D_{3}, D_{4}\right)$

A variety of basic and intermediate rocks is exposed on Flat Top Mounta (figure 5). Some of these rocks have similarities to rocks discussed in otr grouss, but others do not; however, it seems simplest to discuss all as a geographic group.

The most mafic-rich members $\left(D_{1}\right)$ were found along the west side of the southern fart of Flat Tor Mountain. These rocks are gabbros containing 50 to 70 fercent mafic minerals, mostly hornblende, along with plagioclase. Grain size varies from fine to medium. In several cases, a foor foliation vas observed.

The tof of the southern rart of flat Top Mountain and part of the ridc extending southeast from it are corfosed of medium-grained quartz-bearing hornblende qabbro $\left(D_{2}\right)$ typified by specimens $4 A R 223$ and $\triangle A R 235$. plagioclase and hornblende are the major constituents, along with smaller amounts of quartz and biotite. Foliation and banding were observed locally on the ridc southeast of the peak, but have no consistent attitude. Igneous breccia comrosed of dark fragments in a light-colored dioritic matrix was found in several locations in the saddle between the two peaks of Flat Top Mountain.

The northern :art of Flat Top Mountain is composed of biotite granodiorite ( $\mathrm{D}_{3}$. sancle $4 \mathrm{AR} 231$ in Table 1$)$. This rock is light-colored and medium-grained and is shown on maps by Moffit (1912. 1954). It is similar in composition to the intrusives at Meier and Hogan Hill, but differs in being finer-grained and in lacking the muscovite found in those two bodies. This body was visited only along its southern margin but appears quite homogeneous in this area. Slightly coarser-grained granodiorite was found southeast of the southern peak (section 19). The granodiorite locally contains orthoclase phenocrysts as much as a half inch in length.

Coarse-grained quartz-rich granodiorite $\left(D_{4}\right\rangle$ is present on the southern most ridge of Flat Tof Mountain (section 25). No thin section was made of this rock, but an $\mathrm{X}$-ray fluorescence analysis for $\mathrm{K}_{2} \mathrm{O}$ indicates a potash feldspar content of about 10\%. Numerous mafic dikes cut this body. 
Leucocratic biotite granociorite at Meier and Hogan Hill (E)

Light-colored biotite quartz diorite and granodiorite is exposed in the Hogan Hill and heier areas (Eigures 2 and 3 ). Mineralogical compositions of these rocks are shown in Table 1 (samples 4AR19, 4AR44, and 4AR68). The margins of the biotite granodiorite at Meier are strongly foliated, but the central parts of the body are massive, and it is believed that the foliatiol is Erimary and develoced by intrusion of the central fart of the mass while the margins vere largely consolidated. This conclusion is also supported by the fact that narrow aplite dikes cut the foliation but are not deflected by it. The rocks in both areas are medium to coarse-grained, and in addition to their similarity in general composition, both contain primary muscovite along with the biotite. The country rock adjacent to both intrusives has been noticeably metamorchosed, and at leier considerable cataclastic deformation is evident near the contact.

These intrugives are tentatively considered as Jurassic by correlation with muscovite-biotite granodiorite in the eastern Talkeetna Mountains (Grantz, et al, 1963).

Intrusive basalt, andesite and dacite of Flat Tof Mountain area (F)

Porphyritic basalt, andesite, and dacite as plugs and dikes intrude gabbro and granodiorite in the southern part of the Flat Top Mountain area (figure 5). Some bodies are unaltered and are completely aphanitic at contacts but other dikes are chloritized and sheared. The andesite (labeled g?) on the north side of Twelvemile Creek, and the dacite northeast of ieier Lake may be part of the same group of rocks, but are included in the older groui of andesites on a geographic basis.

The age of these hyrabyssal intrusives can be given only as later than the gabbro and coarse granodiorite of intrusive group D. If group $D$ is older than Amrhitheatre basalt, the hypabyssal intrusives may be co-magmatic with the Amphitheatre basalt magma.

STRUCTURE

West of the Gulkana River, the aeromagnetic data plus the few observatic of foliation made in this project suggest that litholigic units in the greenschist-amphibolite group strike approximately east-west. However, in both the Hogan Hill and Meier areas, the Eoliation trends southeast or south. The most obvious interpretation of this change in trend is that the foliation has been deflected around the biotite granodiorite plutong at Hogan $\mathrm{Hill}$ and Meier. No continuation of the beltlike aeromagnetic highs and lows east of the flutons is obvious, and it seems rossible that the granitic rocks 
are intruded in a zone cf more comolex structure. Unfortunately, geologic data for a strip about 25 miles wide on the east side of the Richardson Highway are almost nonexistent.

In the Meiez area, the plunge of minor fold axes is northwest to west at about 50 degrees. At Hogan Hill the axes plunge 50-75 degrees to the ea! and northeast. The significance of this difference is not known.

In gross form, the Amphitheatre basalt appears to occur in a broad syncline with older rocks exposed both north and south. West of the area shown on figure 1, the syncline trends approximately east-west with its axis near the Denali Highway. Near Paxson it curves southeastward. The synclini nature of the north side is clearly indicated by southward dips of flows on Fish Creek (figure 7) and to the northwest near Eureka Creek (Rose, 1965 ). Flows on Paxson Mountain tend to strike northwest and dip gently both to the northeast and southwest. It is therefore concluded that the axis of the syncline is in this vicinity. The south limit of the basalt is fresumea to be synclinal, but coulo equally well be faulted.

In the few exposures not covered by lichens, the Amphitheatre basalt was seen to be cut by numerous fractures, faults, and quartz-epidote veins.' The attitudes of flows also appear to change abruptly in two localities, and vesicular zones could be followed only short distances. Based on this meager evidence, it is concluded that the basalt is broken into numerous small fault blocks, perhaps as a result of folding this brittle rock into a broad syncline.

Taken as a whole, joints in the Paxson Mountain area strike northwest and dip steeply southwest. The strike of the joints parallels the trend of the inferred syncline and may have developed during folding. East-west and north-south trends of joints are fresent on the lower slopes near Paxson and near the north end of the mountain. A series of light-colored hornblenc andesite dikes $\left(\mathrm{B}_{2}\right)$ trends northeastward across the mountain near Paxson and are accompanied by several coarse gabbro or diorite bodies ( $B_{1}$ ). Dikes are also common near the north end of the mountain. As discussed under economic geology, small copfer frospects are concentrated in both areas of dikes and anomalous jointing.

From a regional view, the following tectonic and geologic units can be distinguished (from south to north):

1. Well-foliated greenschist and amphibolite.

2. Unfoliated greenstone, and andesite, intruded by gabbroic and dioritic rocks which may be plutonic equivalents of the Amphitheatre basalt. 
3. Amphitheatre basalt, in the central part of a broac syncline, cut by gabbroic and dioritic intrusives.

4. Permian(?) sediments and volcanics dipping northward under the Amph: theatre basalt.

Units 1, 3, and 4 can be traced westward from the map area for many miles, based on the aeromagretic data and reconnaissance mapping, but do not appear to continue to the east in such simcle form (figure 1). This feature, plus the change in foliation and attitude of the rock units near the Richaräson Highway suggests that an important north-south structural discontinuity may lie between the Richaroson Highway and the Gakona River.

\section{ECONOMIC GEOLOGY}

\section{Paxson Mountain Area}

The occurrence of copper in the Paxson area was noted by Martin (1960, c. 20) as follows: "There is also a low-grade copper deposit in the gulch 1-1/2 or 2 miles west of Paxson's roadhouse". During construction of the Denali Highway, two claims were staked on other copfer shows at Mile 7, and the proscect was visited and reported on by Saunders (1962) of the Division of Mines and Minerals. A dozen or more copper showings are knom farther west in the Amphitheatre basalt (Kaufman, 1964. Saunders, 1961. MacKevett 1964b). Hineralized rock at these prospects typically consist of chalcopyrit bornite, and chalcocite accomøanied by eridote and quartz in vesicular zones, volcanic breccias, and veins or pods. The Kathleen-Margaret crospect (Chapman and Saunders, 1954, Mackevett, 2964a) and locality 8 of Kaufman (I9t which has since been trenched and orilled, are the largest knorm copper occurrences of this tyce. The $\mathrm{K}-\mathrm{M}$ prosfect is on a quartz vein in greenstone cut by diabase and light-coloreo porl:hyry. Locality 8 of Kaufman (1964) consists of coccer sulfides and oxides in a volcanic(8) breccia zone. Limestone and argillite occur nearby, and a gabbro dike cuts the breccia.

About a dozen occurrences of coprer were found on Paxson Mountain and are described below. Locality numbers refer to figure 7.

\section{Locality 1}

At this location, several narrow (less than 1 inch) bornite-chalcopyrite veins cut epidotized vesicularbasalt. The veins strike N85H and dip $75^{\circ} \mathrm{N}$. Asbestiform actinolite occurs in one vein. A few feet away from the copperbearing veins, chrysocolla occurs in vesicles in epidotized basalt. A thin section shows that quartz accompanies the epidote, but that some pyroxene from the basalt remains unaltered. 
A $1 / 4$ inch vein of epidote and quartz striking N30w, vertical, contains bornite partly oxidized to chrysocolla. The vein occurs in altered and highly fractured rock that was probably basalt. A dark aphanitic dike cuts the outcrop. Alteration consists of epidote and chlorite, but does not appe any stronger near the mineralized vein.

\section{Locality 3}

This locality has been Erospected by a pit, and may be the prospect referred to by liartin (1920). The exposure is on the steen east slope of an abandoned glacial stream channel cut in the basalt. Chrysocolla and chalcocite occur in a highly vesicular purflish-brown basalt flow. The relation are sketched in figure 10. The chrysocolla and chalcocite are most abundant near a fracture or fault at the north side of the exposure, and appear to die out near the south side of the vesicular zone. Faulting apparently offsets the mineralized unit at both the north and south sides of the exposure. The mineralized vesicular zone strikes N75E and dips about $35^{\circ}$ N. . A chip sample across a thicliness of 10 feet of the mineralized zone assayed $6.9 \%$ copfei with no gold or silver. Although the grade is very encouraging, the mineralization appears to be limited in every direction exceft into the hill side. Additional geologic study combined rith soil sampling may be effectiv. in finding extensions of the mineralized zone that have been offset by faults.

Locality 4

Several rieces of coffer-stained float containing minor chalcocite were notes in a frost boil at this location.

Locality 5

This cofper show occurs in a zone of limonite-stained rock about 30 feet wide and extending along the wall of a gorge for 250 feet. The zone appears to dip north at about 20 aegrees. The copper staining is at the southern end of the gorge. Pyrite, chalcoryrite, and bornite are associated with quartz-epiaote veinlets and vuggy pods up to a foot long and 6 inches wide. The country rock is highly fractured and chloritized basalt.

Locality 6

Coprer occurs as chrysocolla in a pod of highly altered vesicular basalt. The pod is about $3 \times 2$ feet in size. Vesicular basalt is common in this vicinity, but massive non-vesicular basalt or andesite with abundant hornblende rrisms is exposed 3 feet above the copper-stained zone. Aleratios minerals are quartz, enidote and Erehnite. 


\section{Locality 7}

Several $1 / 2$ inci veinlets of bcrnite cut vesicular Furflish lava at thi location. The veinlets strike $N 3 W$ ano dip $80^{\circ} \mathrm{W}$. Minor amounts of chalcoci accompany the bornite and both minerals are partly oxidized to malachite and chrysocolla. Amygdules in the lava are composed of opal. Float from the mineralized zone could be tracedfor about 100 feet along the strike of the zone.

\section{Locality 8}

An area about 20 feet long and 2-3 feet high on a cliff face in a gorge is coated with chrysocolla and malachite. The source of the copper appears to be a nearly flat zone of vesicular basalt containing minor amounts of bornite. Copfer-bearing float was found in a gully a few tens of feet north, and an old claim sost and several stakes were found at the top of the cliff. Traces of copfer were also found on the opposite side of the gorge. A light-colored hornblende andesite oike cuts the flows a few hundred feet west. The dike and the mineralization at locality 8 are in line with the strike of the bornite veinlets at locality 7 .

\section{Locality 9}

Bornite and quartz occur in a $1 / 2$ inch vein trending N35E. Several pieces of float showing good copror stain were found downslore from the vein.

\section{Locality 10}

lineralization at Hile 7 on the Denali Highway vas staked in 1962 by Jack Trifr of Fairbanis. As can be seen on figure 1l. corner minerals occur in the roadcut near the milerost, and also in rits and outcrops a fev hundred feet southwest. The correr minerals are chalcoyrite, bornite and chalcocite or digenite, rlus chrysocolla and possibly other oxidation r.roducts. Eyrite is present in a few rlaces, especially in the road cut northrest of milerost 7 but is very sparse in the main part of the frospect ano is not generally associated with the cofcer minerals. The colver minerals occur both in and adjacent to veins, pods and amygdules of quartz and epidote. Prehnite was identified in one well-mineralized sampla. The host rock is vesicular basalt, mostly altered to chlorite and some eridote. The veins and cods are generally less than one inch wide, and can be traced only a few feet. A grab sample of quartz veins bearing chalcoryrite and bornite contained $1.38 \%$ copper, a trace of gold, and 0.30 ounces per ton of silver (Saunders, 1962). The exposed mineralized rock appears to be too spotty and low grade to mine, but there is extensive cover to the north and east of the clains and it is possible that better mineralization may exist in the vicinity. 


\section{Other copper occurrences in the Paxaon Area}

Traces of confer minerals were noted at several other locations on Parson Mountain. These are similar to those aiscussed above, and generally amounted to only a few grains or amygdules filled with chalcoryrite. Small amounts were also found in basalt on the east side of parson Lake, north of the microwave relay tower.

Origin of coprer in Parson Mountain area

The geology, mineralogy, and host rock of the copfer rirospects on Paxson Mountain exhibit many similarities to the copper deposits of northern Michigan. In both areas, the host rock is anygdaloidal basalt in which -.lagioclase has been albitized. In northern Michigan, ezidote, quartz, calcite, and rechnite are the main constituents of amygdules, and copper occi in amygdule zones at the tof of flows; rumpellyite, microcline, and laumontit are also locally present. An obvious mineralogical difference is that the copfer in northern Michigan occurr as native copfer, while in the paxson area it is in the form of chalcopyrite, bornite and chalcocite. This difference may not be important in considering the origin of the copper, because minor amounts of chalcocite are Eresent in Michigan, and the formation of the sulfiaes at parson may result from a greater abundance of sulfur in the rocks of the area.

In a recent parer, Stoiber and Davicson (1959) demonstrate a mineralo. gical zoning in the anygdules and show that concentrations of copper occur most commonly near boundaries between alteration types, principaliy near the boundary between eridote and quartz. These writers find that the zoning is regional in extent, and attribute it to "hydrothermal" solutions generated by low grade matamorphism of more deefly-buried farts of the lavas. This theor' seems reasonable for the payson area, in view of the lack of any obvious igneous source related to the mineralization, plus the presence of similar mineral occurrences throughout the Amphitheatre basalt.

As discussed under structure, the copper frospects are concentrated in areas of anomalous jointing and dike intrusion. The presence of structures cutting through the flows, flus a higher-than-average abundance of vesicular zones along the northeast side of yaxson Mountain may have allowed relative free circulation of conver-bearing solutions.

Areas south of Paison Lake

Minor to trace amounts of copzer were founa in the following locations:

1. Traces of chalcopyrite occur with magnetite in greenschist and sheareo diorite about $1 / 4$ mile northwest of Meier Lake. The magnetite occurs in irregular pods uc to an inch wide and a few inches long. 
2. Pyrite and traces of chalcopyrite occur on Eractures in biotite granodiorite in a quarry near the north end of the Hogan Hill outcrop area. Rock adjacent to the fractures is partly altered to orthoclase and chlorite.

3. In a quarry near the north end of the amphibolite exposures on Hogan Hill, small chalcopyrite-quartz veins are locally present along Foliation. Minor copper stain was also noted near the southern end of Hogan Hill.

Several magnetic anomalies of 1500-2500 gammas are shown on the map of Andreason and others (1964). These anomalies probably result from magnetite in the greenschist. However, some mobilization of magnetite may have taken place to cause the strongest parts of the anomalies. If so, base metals might also be concentrated in these areas.

GEOCHEMICAL DATA

Locations of stream sediment samples are shown on figures 2 to 9 and oata are in Table 2. The field results represent readily extractable copper, lead, and zinc by the University of Alaska cold extraction field procedure (Mukherjee and Mark Anthony, 1957). The analyses for copper, lead, zinc, molybdenum, and nickel were done by the Division of Mines and Minerals laboratories and Rocky Mountain Geochemical Laboratories using colorimetric methods designed to measure total metal content. These methods have been more completely discussed elsewhere (Rose, 1965).

For copper, the background averages about 50 parts per million (ppm) in stream sediments from the area, and a value of 100 ppm is taken as the lower limit or threshold of anomalous values. For zinc. background is mostly in the range 40-100 ppro, and $125 \mathrm{ppm}$ is taken as threshold. For lead, most values are $5-15 \mathrm{ppm}$ and $30 \mathrm{ppm}$ is taken as threshold. For molyb. denum, a value of $5 \mathrm{fpm}$ is taken as threshold. For nickel, it is likely that background differs afpreciably for different rock types, but too few samples were analyzed for nickel to determine probable threshold values. Samples 530 and 532 may be anomalous.

Of the known copper occurrences on Paxson Mountain, anomalous results were obtained only below locality 1 (sample R116). Sample 4WP4l. just belor locality 10. is not anomalous desnite the oresence of sparse pieces of coffer-bearing float in the stream. It thus appears that rueakly anomalous copper values in samples 4WP68, 4WP110, and 4ARl96 may be derived from larger or more strongly mineralized areas than locality 10 . However, these anomalies are still quite weak to be caused by an ore deposit. 
The anomalies snown by samples $576,79,80,81,82,83,84,85,86,87$ and 88 deserve more follow-uo work. The lithology in this :rea is apparent: mainly basalt or other mafic rocks, based on observations while collecting stream sediments. Contamination during processing is another alternative, but other than the fact that every sample in tinis sequence is anomalous, there is nothing to suggest this.

The anomalies in total metal in the southern part of the area are relatively weak, with the lead content of sample W239 in the Twelvemile Creek area being the only strong anomaly. In addition to the total metal anomalie: in samples $\mathrm{H} 2,569$, W9, and $\mathrm{W} 239$, anomalies in readily-extractable metal were found in samples 562, S64, W250, and W251. These could result from an oxidizing sulfide body not exposed to physical erosion.

The following minerals were identified by Donald Stein. Assayer, Division of Mines and Minerals, in a panned concentrate from location S56: magnetite, chromite, ilmentite, olivine, zircon, scheelite, gold and sphalerite, plus a number of silicates. A trace of lithium was detected in spectroscopic examination. Glacial till may be the source of some of these minerals, but granite has been reported in this vicinity.

SUMMARY

The oldest rocks mapped in this project are pre-Triassic greenschists and amphibolites in the Meier and Hogan Hill areas. The greenschist and amphibolite underwent regional metamorphism accompanied by folding along east-west to southeast axes. Frobably in late Paleozoic time, before eruption or intrusion of greenstone and andesite in the Meier and Twelvemil creek areas. Permian shale, limestone, and volcanic rocks were deposited on the north side of the area, but are not recognized in the southern part. Eruption of a thick sequence of mafic volcanics in Triassic time produced the Amphitheatre basalt. Gabbro and diorite intrude the Amphitheatre basal. and may have formed as gart of the same magmatic efoch. Two leucocratic biotite granodiorite olutons of Jurassic(?) age intrude the fre-Triassic rocks in the southern fart of the area, and gabbro, diorite and granodiorit, of uncertain age are present in the Flat Top Mountain, Meier and Twelvemile creek areas. The location of the granodiorite intrusives, combined with apfarent deflection and termination of well-defined tectonic trends suggest that a major change in structural pattern occurs approximately along the Richardson Highway. A broad syncline with its axis along the belt of Amphi. theatre basalt may have ceveloped sometime between Jurassic and Middle Tertiary.

Small copper denosits on Paxson Mountain occur mainly in vesicular zones in Amphitheatre basalt. The coffer occurrences are clustered in area of dikes and anomalous joint trenos. Chalcopyrite, bornite, and chalcocite in the deposits are associated with epidote, quartz, calcite, chlorite, and frehnite as veins, pods, anygdules, and reglacements of rock minerals. The 
deposits are similar in geologic setting, gangue minerals, and local struct. ural control to the copper deposits of northern Michigan, but oiffer in containing copper sulfides rather than dominantly native copper.

Numerous stream sediment samples from an area in the Amphitheatre Mountains are weakly to moderately anomalous in copper, zinc, and lead. scattered samples elsewhere are weakly anomalous in one of these metals.

\section{SUGGESTIONS FOR PROSPECTING}

The geochemical anomalies in the Amphitheatre Mountains north of the Denali Highway deserve follow-up by additional sampling and prospecting. Because of the variety of metals present, the source does not appear to be a copper deposit of the type found on Paxson Mountain. The lead and zinc anomalies in the. Twelvemile creek area (W239, s69) and Meier area (H2) meril resampling and further work.

Assuming that the analogy with the copper deposits of northern Michigas is correct, a more thorough structural and mineralogical study of the entire belt of Amphitheatre basalt, using the criteria described by stoiber and Davidson (1959), might allow selection of preferred parts of the belt for mineral deposits. However, in view of the relatively smail amount of prospecting done to date in the area, it is probable that stream sediment sampling and ordinary prospecting are a cheaper and faster method of findinc the more obvious deposits in the belt.

A rapid examination of the stronger magnetic anomalies in the southern part of the area seems justified to evaluate them for iron and other metals. 


\section{BIBLIOGRAPHY}

Andreason, G.E., Grantz, A., zietz, I., and Barnes, D.F., 1964, Geologic Interpretation of Magnetic ana Gravity Data in the Copper River Basin, Alaska: U.S. Geological Survey Prof. Paper 316H, p. 135-153.

Chapin. T., 1918, The Nelchina-Susitna Region, Alaska: U.S. Geological Surv Bulletin 668, $67 \mathrm{p}$.

Chapman, R.M., and Saunders, R.H., 1954, The Kathleen-Margaret (K-M) Copper Prospect on the Upper Maclaren River, Alaska: U.S. Geological Survey Circular $332,5 \mathrm{p}$.

Grantz, A., Thomas, H., Stern, T.W., and Sheffey, N.B., 1963, Potassium-Argi and Lead-Alpha Ages for Stratigraphically Bracketed Plutoric Rocks in the Talkeetna Mountains, Alaska: U.S. Geological Survey Prof. Paper 4758, I. B56-B59.

Kaufman, Y.A., 1964, Geology and Mineral Deposits of the Denali-Maclaren River Area, Alaska: Alaska Division of Mines and Minerals, Geologic Report 4.

Mackevett, E.M., 1964a, Ore Controls at the Kathleen-Margaret (Maclaren River) Copper Deposit, Alaska: U.S. Geological Survey Prof. Paper 501. C.. P. Cl17-C120.

Mackevett, E.M., 1964b, Nikolai Greenstone of Wrangell Mountains near Kennicott, Alaska: Geological Soc. Am. Cordilleran Section, program of meeting in Seattle, March 1964, F. 41.

Martin, G.C.. 1920, The Alaskan Mining Industry in 1918: U.S. Geological Survey Bulletin 712, p. 20.

Mendenhal1, W.C., 1905, Geology of the Central Copper River Region, Alaska: U.S. Geological Survey Prof. Paper 41, $133 \mathrm{p}$.

Moffit, F.H., 1912. Headwater Regions of Gulkana and Susitna Rivers, Alaska U.S. Geological Survey Bulletin 498, 82 p.

Moffit, F.H., 1938, Geology of the Chitira Valley and Adjacent Area, Alask U.S. Geological Survey Bulletin $894,137 \mathrm{p}$.

Moffit, F.H., 1954, Geology of the Eastern Part of the Alaska Range and Adjacent Area: U.S. Geological Survey Bulletin 989D, p. 63-218.

Mukherjee, N.R., and Mark Anthony, L., 1957, Geochemical Prospecting: University of Alaska, School of Mines Bulletin 3, 81 F. 
Pewe, T.L.. 1961, Multiple Glaciation in the Headwaters Area of the Delta River, Central, Alaska: U.S. Geological survey Prof. Paper 424D, P D200-D201.

Rose, A.W.. 1965, Geology and Mineral Deposits of the Rainy Creek Area, Central Alaska Range: Alaska Division of Mines and Minerals, Geologic Report $14,51 \mathrm{p}$.

Ross, C.P., 1933, The Valdez Creek Mining District, Alaska: U.S. Geologica: Survey Bulletin $849 H$, p. 425-468.

Saunders, R.H., 1962, Refort on the Examination of the Tripp Copper Prospect Mt. Hayes Quadrangle: Alaska Division of Mines and Minerals, unpublished report, $2 \mathrm{p}$.

Stoiber, R.E., and Davidson, E.S., 1959, Amygdule Mineral zoning in the Portage Lakè Lava Series, Michigan Copper District: Economic Geol. v.54. P 1250-1277, 1444-1460. 
Table 1 - Mineralogical Composition

27

Quartz

K-feldspar

Plagioclase

Augi te

Hornblende

Actinolite

Biotite

Chlorite

Epidote

Muscovite-sericite

Carbonate

Opaque oxides

Pyrite

Apatite

1 Sphene

6 Nane

Intrusive Group

35

5

15

tr
1 Gabbro

$\mathrm{A}_{2}$

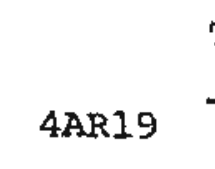

4

4H16 of Intrusive Rocks

ive Rocks

4AR68

\section{AR174}

4AR223 4AR231

4AR2 35

$30\left(\right.$ An $\left._{0-10}\right)$

21
6
$64\left(\operatorname{An}_{30}\right)$

$44\left(A n_{0}\right) \quad 53\left(A n_{25-30}\right)$

3

$\operatorname{tr}$

Diorite Grano-
or diorite tr

4

29

12
5

5

1 tr

tr

tr

Quartz
Diorite

E

$A_{1}$

$\begin{array}{ccr}5 & 3 & 2 \\ & 1 & 10 \\ 2 & 1 & \\ t r & & \\ & & \\ \text { tr } & \text { tr } & \\ \text { Grano- } & \text { Gxano- } & \text { Gabbro } \\ \text { diorite } & \text { diorite } & \end{array}$

30

7 $59\left(\operatorname{An}_{15}\right) 28\left(\operatorname{An}_{55}\right)$ $55)^{4}\left(\mathrm{An}_{35}\right)$

10

$$
5
$$

29

13

$4 I\left(A_{30}\right) 50\left(A_{55}\right.$ )

25

5

5

1

10

$\begin{array}{rr}5 & 10 \\ & 2\end{array}$

$1 \operatorname{tr} \quad 1$

$\operatorname{tr}$

2 tr

Quartz Grano- Quartz Diorite diorite Gabbro

E $\quad$ E
E C
$\mathrm{D}_{2} \quad \mathrm{D}_{3}$

$\mathrm{D}_{2}$

4H16 Coarse diorite or gabbro from ridge northwest of Meier.

4 ARl9 Gneissic biotite granodiorite from road cut at Meier Lake.

4AR 38

4AR 44 Quartz diorite intruding greenstone in NW corner, section 9, Tl2N-RlW. (Meier area)

4AR65

4AR174

4AR2 23

4AR2 31

Biotite quartz diorite or granodiorite, quarry at north end of Hogan Hill outcrop.

Gabbro, Amphitheatre Mountain about 13/s miles NW of Mile 8, Denali Highway.

4AR2 35 Moderately foliated quartz diorite or granodiorite, SW Section 18, T13N-R2W (Flat Top Hrea) Biotite granodiorite, west side section 1, Tl3N-R3W, (Flat Top area). Quartz-bearing gabbro, center Section 13, T13N-R3W (Flat Top area). 
Table 2

Geochemical Data on Stream Sediments

\begin{tabular}{ccccccc} 
Sample No. Field Test & Copper & Zinc & Lead & Moly. Nickel & Fig. No. \\
\hline$(\mathrm{ml})$ & $(\mathrm{ppm})$ & $(\mathrm{ppm})$ & $(\mathrm{ppm})$ & $(\mathrm{ppm})$ & $(\mathrm{ppm})$ &
\end{tabular}

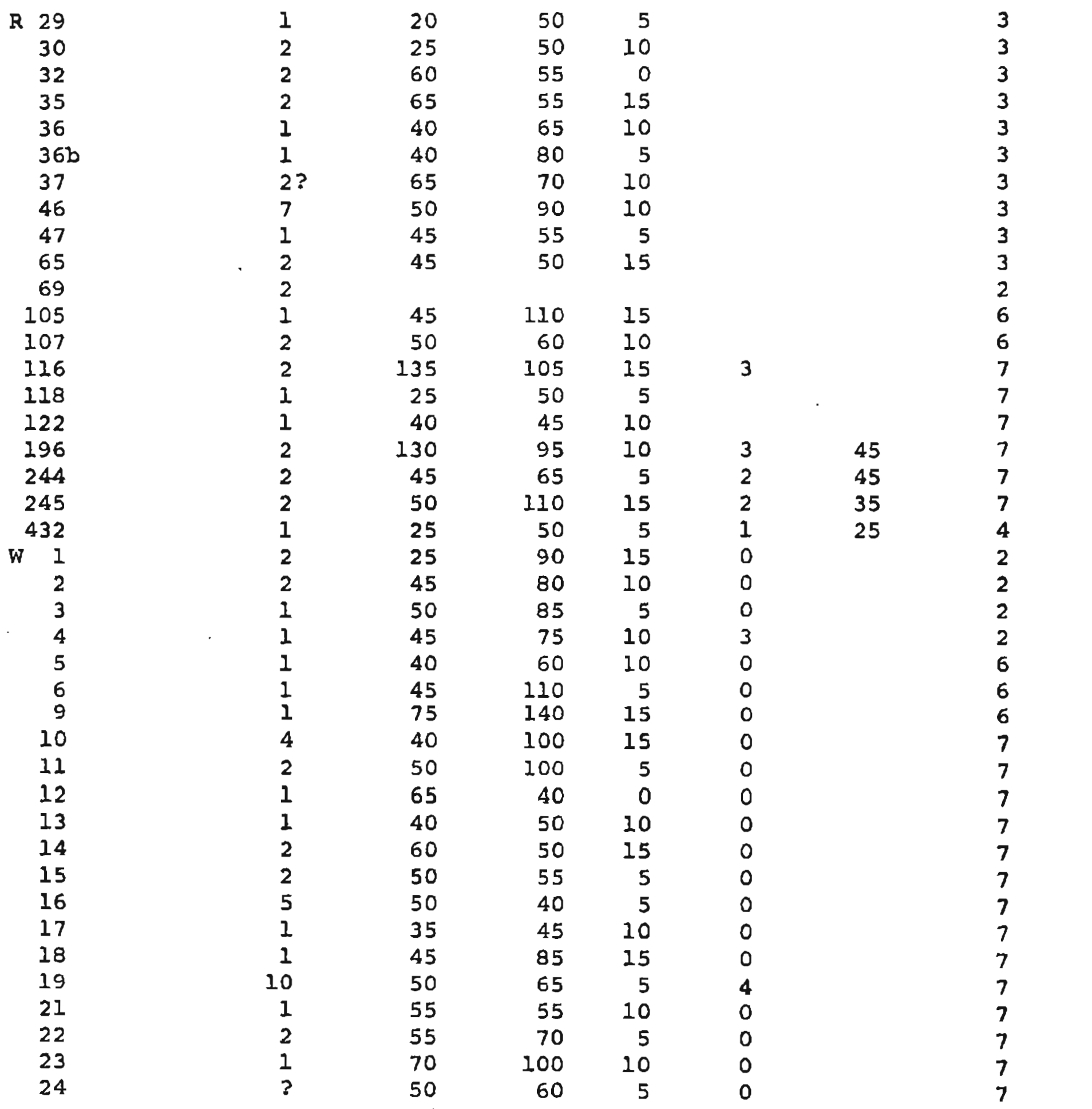


\begin{tabular}{cccccccc} 
Sample No. & Field Test & Copper & Zinc & Lead & Moly. & Nickel & Fig. No. \\
\hline$(\mathrm{ml})$ & $(\mathrm{ppm})$ & $(\mathrm{ppm})$ & $(\mathrm{ppm})$ & $(\mathrm{ppm})$ & $(\mathrm{ppm})$ &
\end{tabular}

\begin{tabular}{|c|c|c|c|c|c|c|c|}
\hline W 25 & 1 & 45 & 55 & 15 & 0 & & 7 \\
\hline 26 & 1 & 50 & 90 & 10 & 0 & & 7 \\
\hline 27 & 1 & 40 & 70 & 5 & 0 & & 7 \\
\hline 28 & 2 & 45 & 65 & 0 & 0 & & 7 \\
\hline 29 & $10 ?$ & 85 & 70 & 5 & 0 & & 7 \\
\hline 30 & 1 & 75 & 90 & 10 & 0 & & 7 \\
\hline 31 & 1 & 50 & 80 & 15 & 3 & & 7 \\
\hline 32 & & 35 & 65 & 5 & 0 & & 7 \\
\hline 33 & 1 & 50 & 65 & 10 & 0 & & 7 \\
\hline 34 & 4 & 50 & 70 & 0 & 0 & & 7 \\
\hline 35 & 1 & 65 & 85 & 15 & 0 & & 7 \\
\hline 36 & 1 & 55 & 70 & 10 & 0 & & 7 \\
\hline 37 & 1 & 70 & 90 & 10 & 0 & & 7 \\
\hline 38 & 1 & 50 & 80 & 15 & 0 & & 7 \\
\hline 39 & 1 & 45 & 60 & 5 & 0 & & 7,8 \\
\hline 40 & 1 & 75 & 90 & 15 & 0 & & 7,8 \\
\hline 41 & 1 & 65 & 80 & 10 & 0 & & 7,8 \\
\hline 42 & 1 & 45 & 80 & 5 & 0 & & 7. 8 \\
\hline 43 & 1 & 65 & 65 & 5 & 0 & & 7 \\
\hline 44 & 1 & 60 & 70 & 5 & 0 & & 7 \\
\hline 45 & 3 & 40 & 30 & 5 & 0 & & 7 \\
\hline 52 & 1 & 50 & 80 & 5 & 0 & & 7 \\
\hline 53 & 1 & 50 & 90 & 10 & 0 & & 7 \\
\hline 54 & 1 & 45 & 60 & 5 & 0 & & 7 \\
\hline 55 & 2 & 35 & 55 & 0 & 0 & & 7 \\
\hline 56 & $6 ?$ & 40 & 55 & 5 & 0 & & 7 \\
\hline 57 & 1 & 40 & 55 & 5 & 0 & & 7 \\
\hline 58 & 2 & 45 & 60 & 0 & 0 & & 7 \\
\hline 59 & 2 & 40 & 100 & 10 & 0 & & 7 \\
\hline 60 & 2? & 35 & 45 & 5 & 0 & & 7 \\
\hline 68 & 3 & 110 & 110 & 5 & 1 & & 7,8 \\
\hline 92 & 1 & 85 & 40 & 5 & 0 & & 7 \\
\hline 103 & 1 & 50 & 40 & 5 & 1 & & 7 \\
\hline 104 & 2 & 35 & 50 & 25 & 1 & & 7 \\
\hline 105 & $2^{\prime}$ & 50 & 70 & $<25$ & 1 & & 7 \\
\hline 107 & 1 & 50 & 45 & 5 & 1 & & 7 \\
\hline 108 & 1 & 45 & 45 & 5 & 2 & & 7 \\
\hline 110 & 1 & 130 & 55 & 0 & 1 & & 7 \\
\hline 112 & $I$ & 55 & 50 & 5 & 1 & & 7 \\
\hline 113 & 3 & 85 & 50 & 20 & 1 & & 7 \\
\hline 114 & 2 & 90 & 50 & 5 & 1 & & 7 \\
\hline 121 & 1 & 85 & 55 & 0 & 0 & & 8 \\
\hline 132 & 2 & 20 & 35 & 5 & 0 & & 5 \\
\hline 133 & 11? & 35 & 80 & 5 & 1 & 50 & 5 \\
\hline 237 & 1 & 25 & 50 & 5 & 3 & & 4 \\
\hline 238 & 5 & 20 & 45 & 5 & 3 & & 4 \\
\hline
\end{tabular}




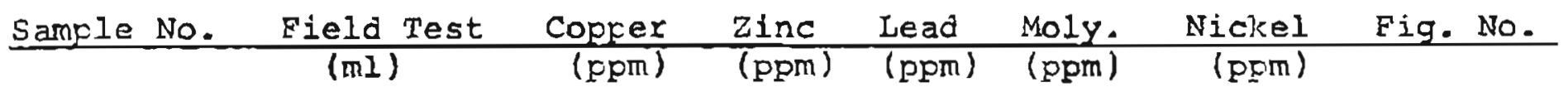

\begin{tabular}{|c|c|c|c|c|c|c|c|}
\hline W239 & 1 & 40 & 145 & 100 & 3 & & 4 \\
\hline 240 & 1 & 20 & 65 & 5 & 3 & & 4 \\
\hline 241 & 1 & 35 & 40 & 5 & 3 & & 4 \\
\hline 242 & 1 & 30 & 55 & 10 & 3 & & 4 \\
\hline 243 & 1 & 20 & 40 & 5 & 3 & & 4 \\
\hline 244 & 2? & 20 & 35 & 5 & 3 & & 4 \\
\hline 245 & $1 ?$ & 15 & 35 & 5 & 3 & & 4 \\
\hline 246 & $2 ?$ & & & & & & 4 \\
\hline 247 & 1 & 20 & 40 & 5 & 3 & & 4 \\
\hline 248 & $2 ?$ & 35 & 65 & 5 & 3 & & 4 \\
\hline 249 & 1 & 35 & 50 & 5 & 3 & & 4 \\
\hline 250 & 10? & 20 & 45 & 5 & 2 & 15 & 4 \\
\hline 251 & $25 ?$ & 30 & 50 & 5 & 2 & 35 & 4 \\
\hline 252 & 1 & 20 & 40 & 10 & 3 & & 4 \\
\hline $\mathrm{H} \quad 2$ & 1 & 50 & 55 & 35 & & & 3 \\
\hline 3 & 1 & 75 & 75 & 20 & 4 & & 3 \\
\hline 6 & 2 & 25 & 50 & 0 & & & 3 \\
\hline l1 1 & 1 & 40 & 65 & 5 & & & 3 \\
\hline 2 & 2 & 50 & 50 & 5 & & & 3 \\
\hline S 16 & 2 & 45 & 40 & 5 & 3 & 40 & 9 \\
\hline 17 & 5 & 45 & 40 & 5 & 3 & 190 & 9 \\
\hline 18 & 2 & & & & & & 9 \\
\hline 19 & 2 & & & & & & 9 \\
\hline 20 & 2 & & & & & & 9 \\
\hline 21 & 2 & & & & & & 9 \\
\hline 22 & 2 & & & & & & 9 \\
\hline 23 & 1 & & & & & & 9 \\
\hline 24 & 2 & & & & & & 9 \\
\hline 25 & 2 & & & & & & 7 \\
\hline 26 & 2 & & & & & & 7 \\
\hline 27 & 2 & & & & & & 8 \\
\hline 28 & 2 & & & & & & 9 \\
\hline 29 & 2 & & & & & & 9 \\
\hline 30 & 8 & 125 & 100 & 0 & 3 & 350 & 9 \\
\hline 31 & 2 & & & & & & 8 \\
\hline 32 & 1 & 70 & 70 & 20 & 3 & 225 & 8 \\
\hline 33 & 1 & & & & & & 8 \\
\hline 34 & 1 & & & & & & 8 \\
\hline 35 & 1 & & & & & & $B$ \\
\hline 36 & 1 & & & & & & B, \\
\hline 37 & 1 & & & & & & 7,8 \\
\hline 38 & 1 & & & & & & 9 \\
\hline 39 & 2 & & & & & & 9 \\
\hline 40 & 2 & & & & & & 8 \\
\hline 41 & 2 & & & & & & 8 \\
\hline
\end{tabular}


\begin{tabular}{cccccccc} 
Sample No. Field Test & Copper & Zinc & Lead & Moly. & Nickel & Fig. No. \\
\hline (ml) & $(\mathrm{ppm})$ & (ppm) & (ppm) & (ppm) & (ppm) &
\end{tabular}

\begin{tabular}{|c|c|c|c|c|c|c|c|}
\hline$S 42$ & 2 & & & & & & 8 \\
\hline 43 & 1 & & & & & & 8 \\
\hline 44 & 11 & 45 & 65 & 0 & 2 & & $B$ \\
\hline 45 & 1 & & & & & & 8 \\
\hline 46 & 1 & & & & & & 8 \\
\hline 48 & 15 & 35 & 70 & 10 & 2 & & 8 \\
\hline 49 & 1 & & & & & & 8 \\
\hline 50 & 2 & & & & & & 3 \\
\hline 51 & 3 & 20 & 85 & 10 & 2 & & 6 \\
\hline 52 & 6 & 30 & 80 & 10 & 2 & & 6 \\
\hline 53 & 1 & 35 & 60 & 5 & 2 & 30 & 6 \\
\hline 54 & 1 & & & & & & 7 \\
\hline 55 & 2 & & & & & & 8 \\
\hline 56 & 2 & & & & & & 8 \\
\hline 61 & 1 & 55 & 35 & 20 & 3 & & 4 \\
\hline 62 & 20 & 55 & 95 & 10 & 3 & & 4 \\
\hline 63 & 2 & 20 & 50 & 10 & 3 & & 4 \\
\hline 64 & 20 & 45 & 110 & 5 & 3 & & 4 \\
\hline 65 & 3 & 20 & 35 & 10 & 3 & & 4 \\
\hline 66 & 1 & 40 & 80 & 5 & 4 & & 4 \\
\hline 67 & 2 & 20 & 35 & 5 & 3 & & 4 \\
\hline 68 & 1 & 10 & 35 & 10 & 3 & & 4 \\
\hline 69 & 1 & 10 & 25 & 35 & 3 & & 4 \\
\hline 71 & 1 & 15 & 25 & 0 & 2 & 55 & 9 \\
\hline 72 & 1 & 45 & 50 & 15 & 3 & 50 & 9 \\
\hline 73 & 1 & 60 & 65 & 5 & 4 & 170 & 9 \\
\hline 74 & 1 & 40 & 35 & 10 & 3 & 80 & 9 \\
\hline 75 & 1 & 75 & 80 & 0 & 4 & 50 & 9 \\
\hline 76 & 1 & 110 & 50 & 10 & 5 & 85 & 9 \\
\hline 77 & 2 & 75 & 80 & 5 & 3 & 55 & 9 \\
\hline 79 & 3 & 70 & 130 & 10 & 3 & 90 & 9 \\
\hline 80 & 1 & 200 & 400 & 20 & 10 & 120 & 9 \\
\hline 81 & 4 & 130 & 400 & 30 & 5 & & 9 \\
\hline 82 & 2 & 130 & 80 & 15 & 4 & 60 & 9 \\
\hline 83 & 1 & 85 & 170 & 5 & 3 & 50 & 9 \\
\hline 84 & 1 & 80 & 125 & 15 & 4 & 80 & 9 \\
\hline 85 & 1 & 120 & 80 & 10 & 3 & 85 & 9 \\
\hline 86 & 1 & 140 & 80 & 10 & 3 & 115 & 9 \\
\hline 87 & 20 & 190 & 480 & 35 & 8 & & 9 \\
\hline $8 B$ & 2 & 75 & 300 & 10 & 7 & 80 & 9 \\
\hline
\end{tabular}




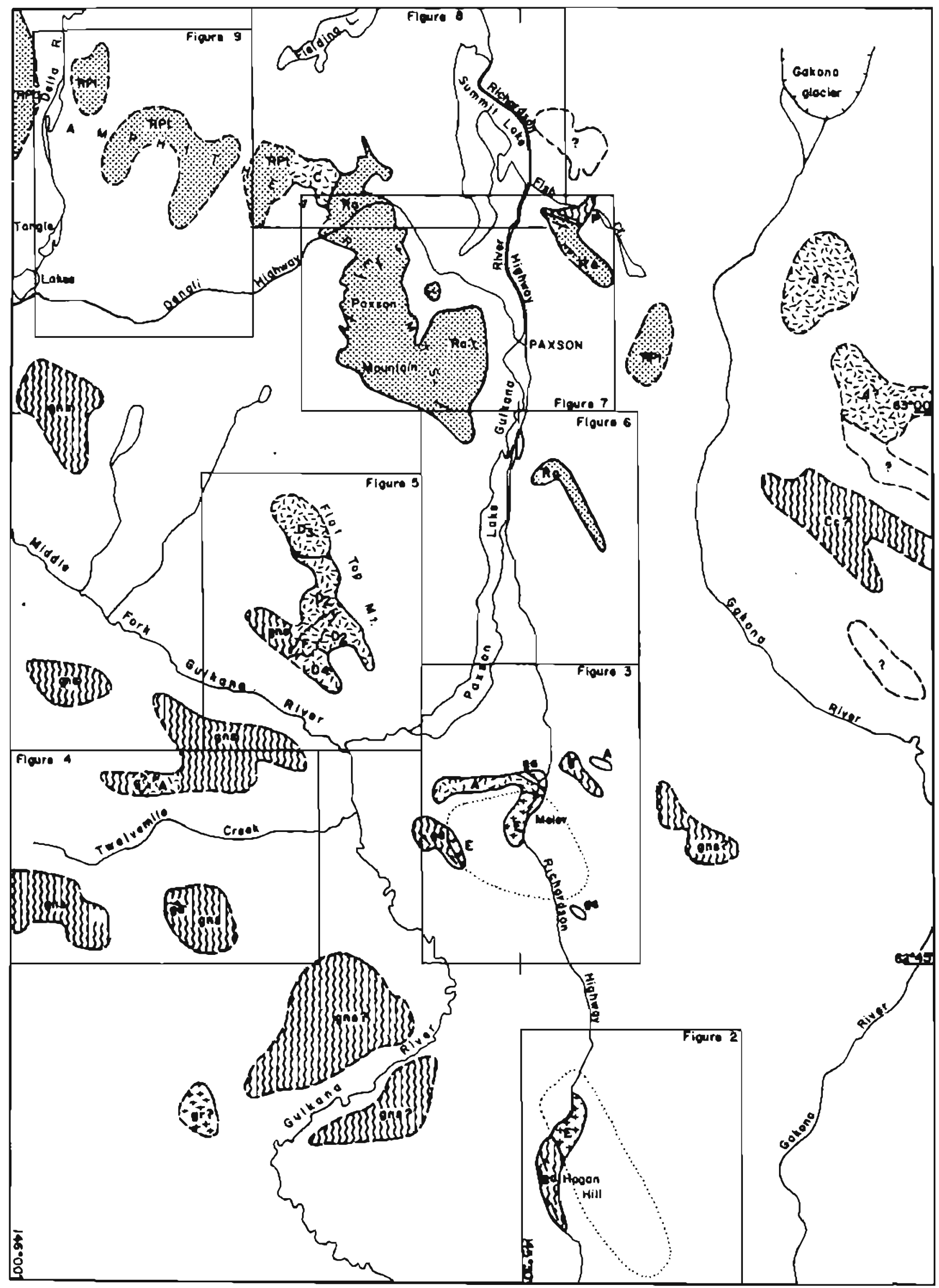




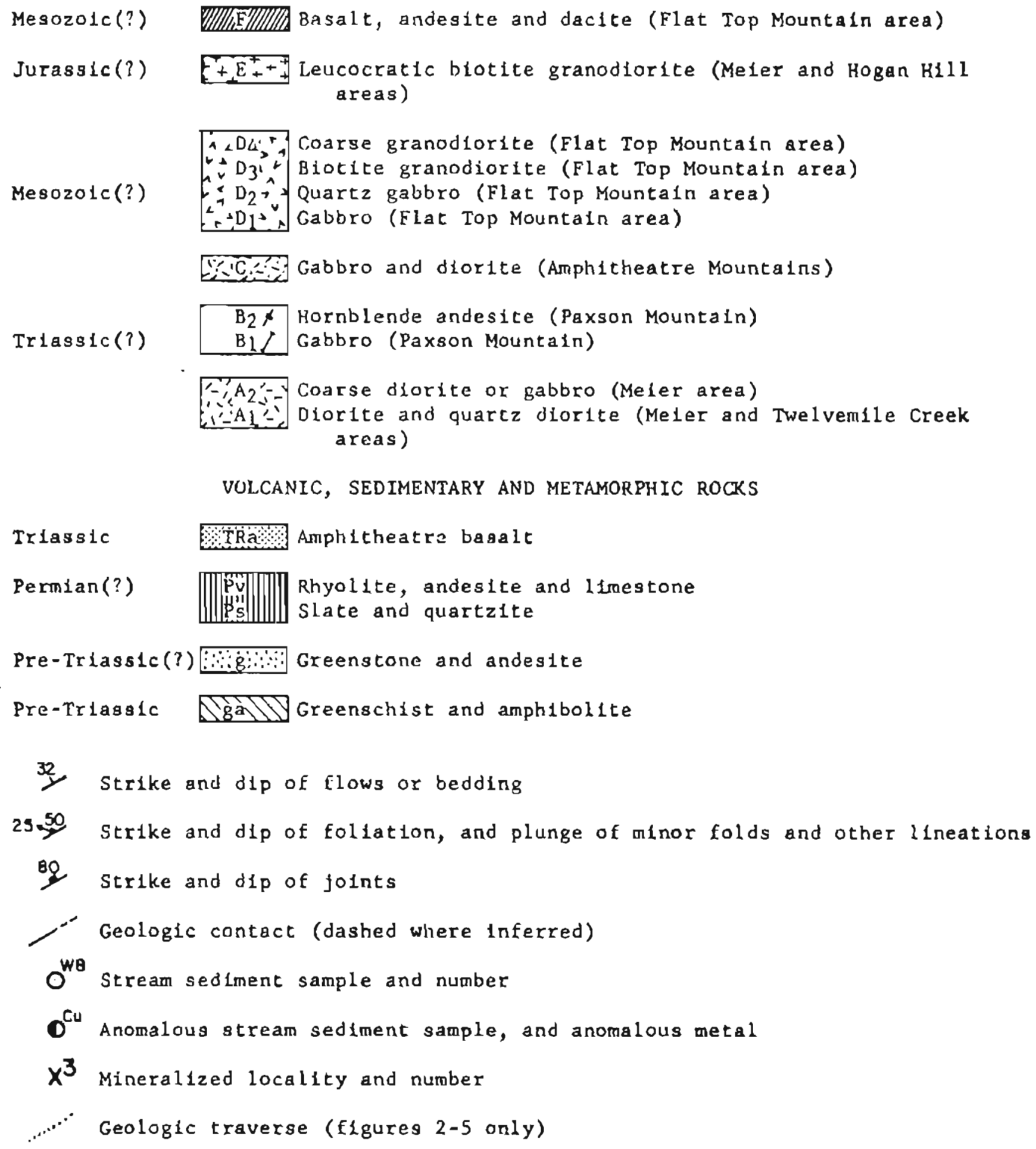




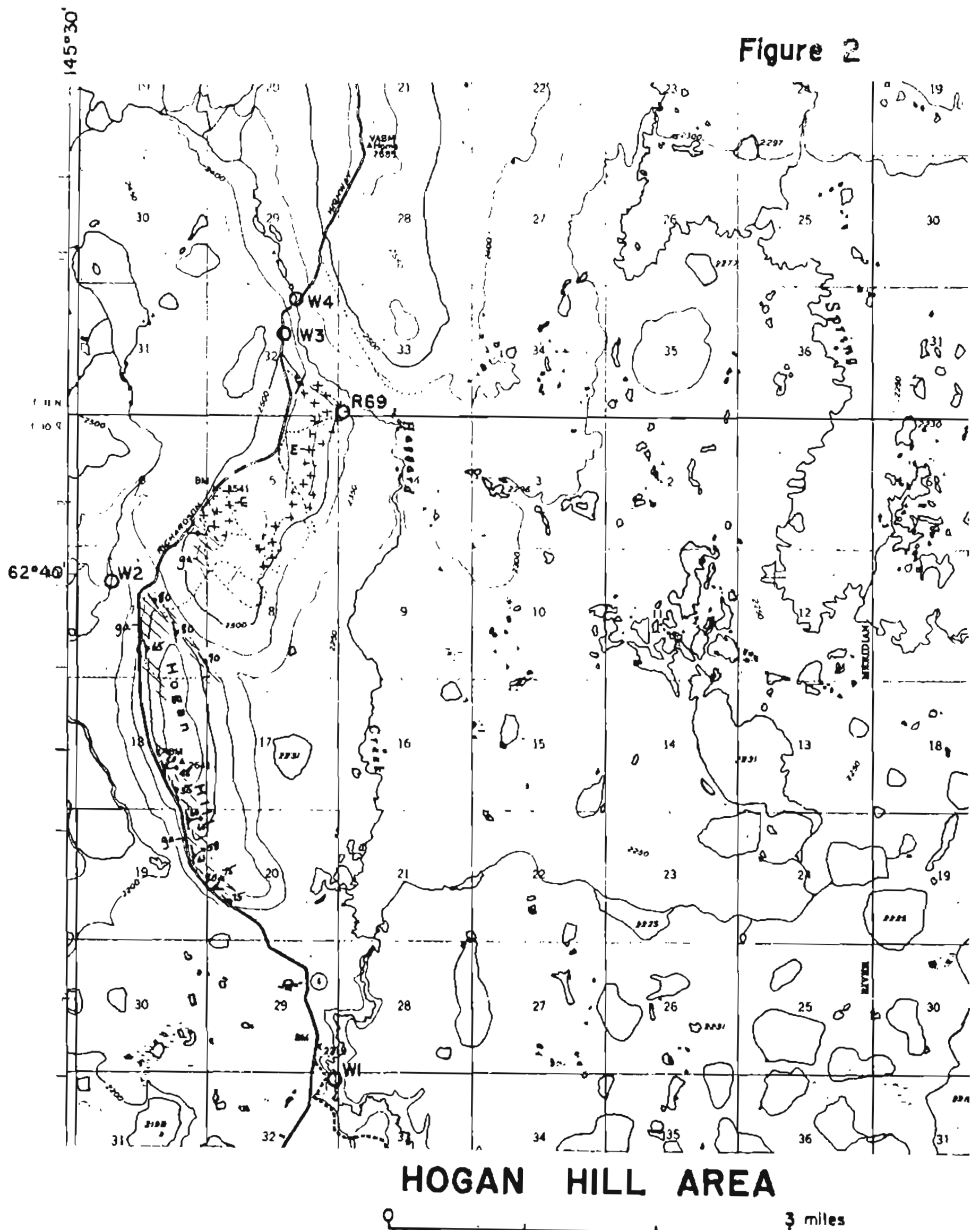

See separate legend 


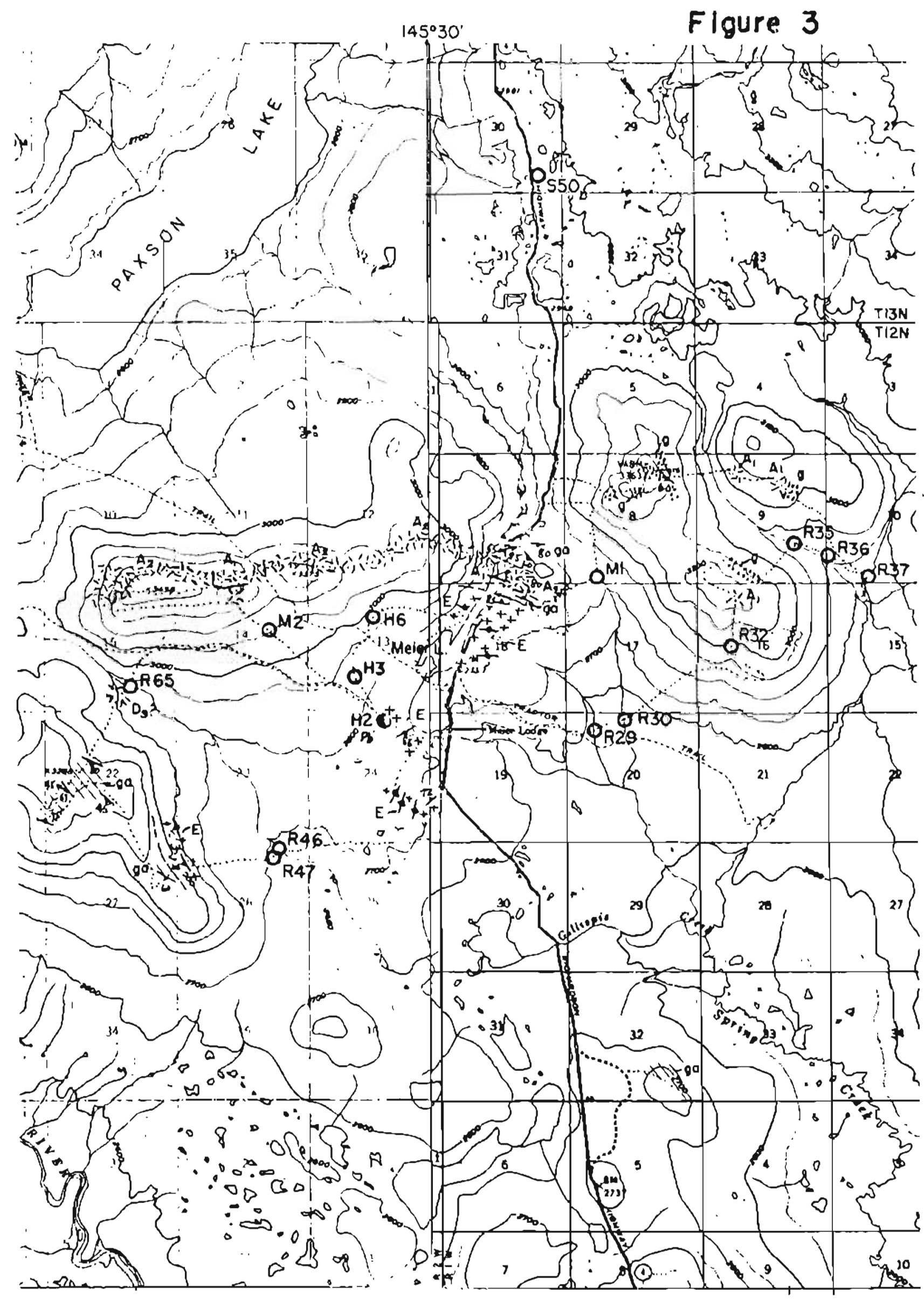

MEIER AREA

$62^{\circ} 45^{\prime}$ 


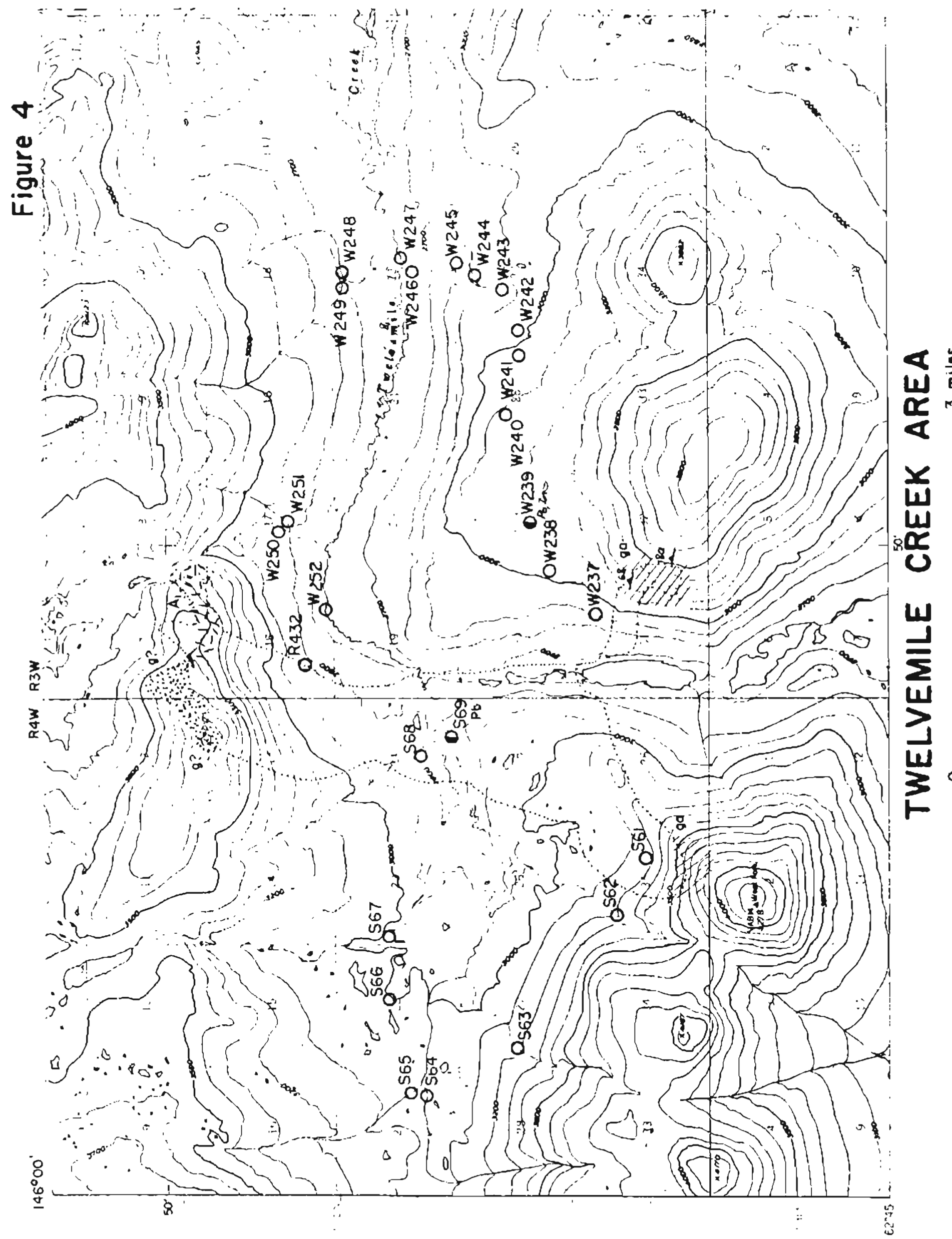




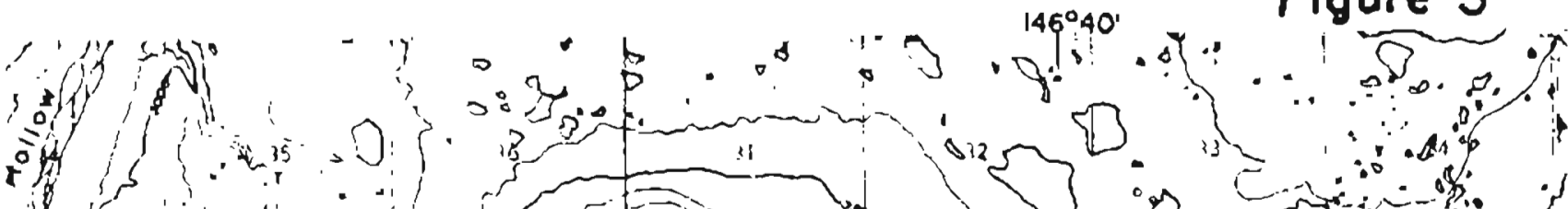
$4 \int^{2}$

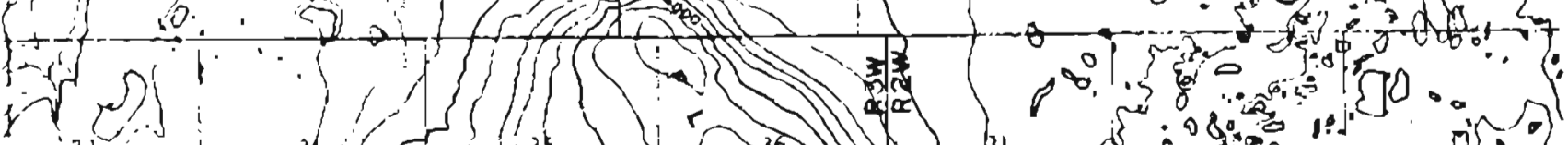
1 $8^{\circ}$.

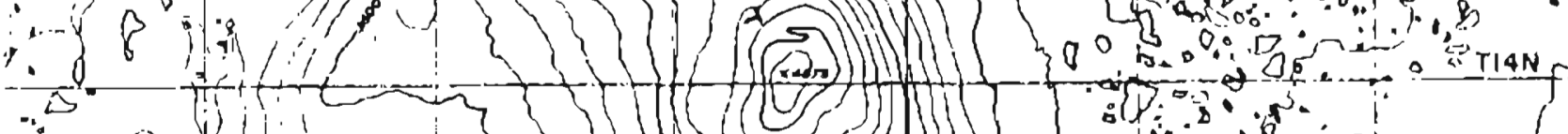
a
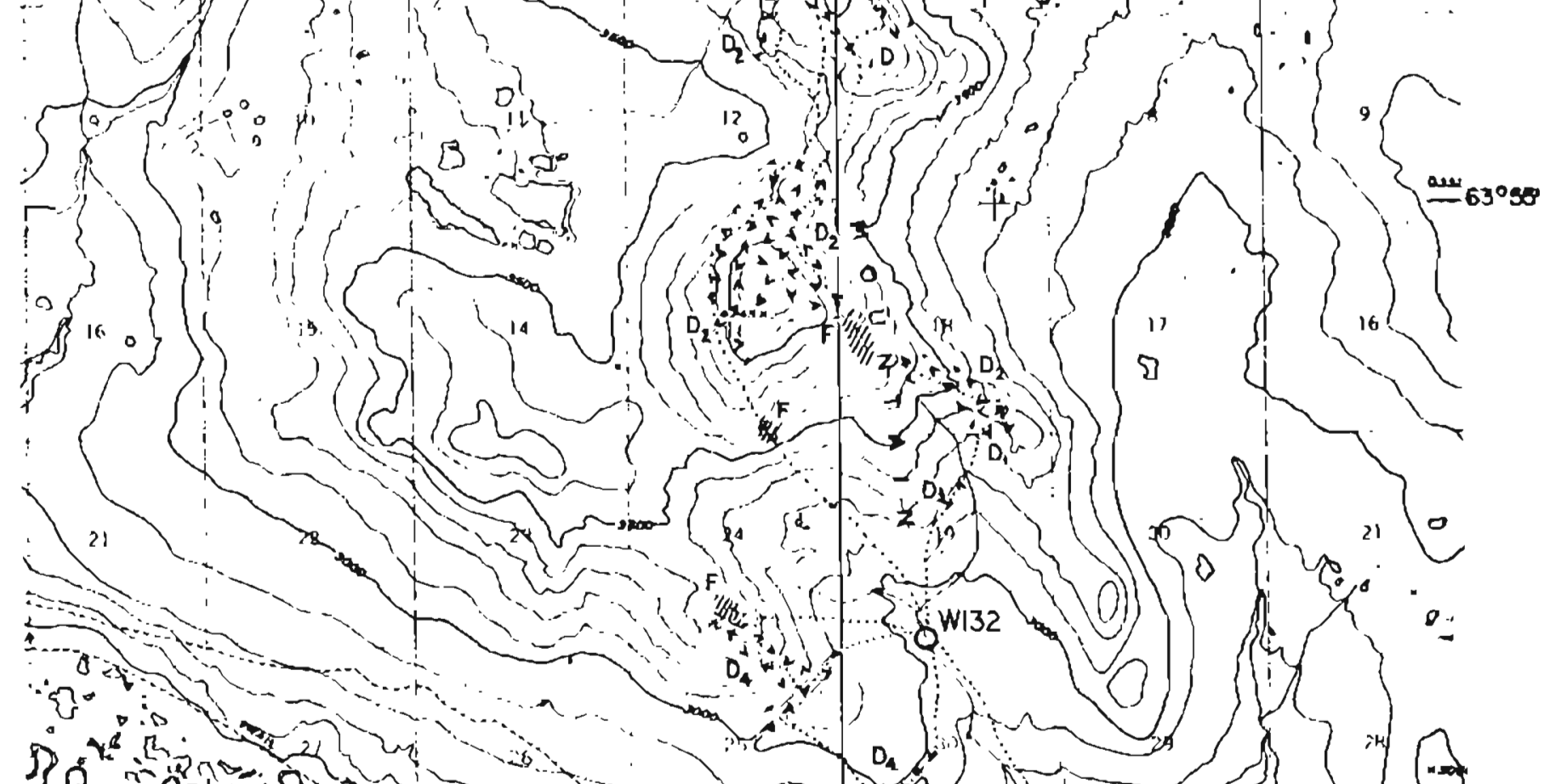

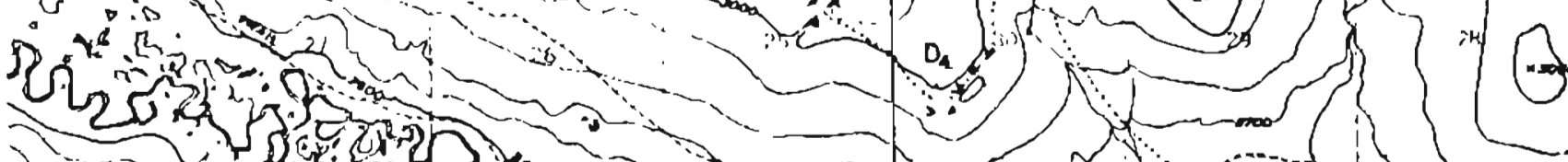

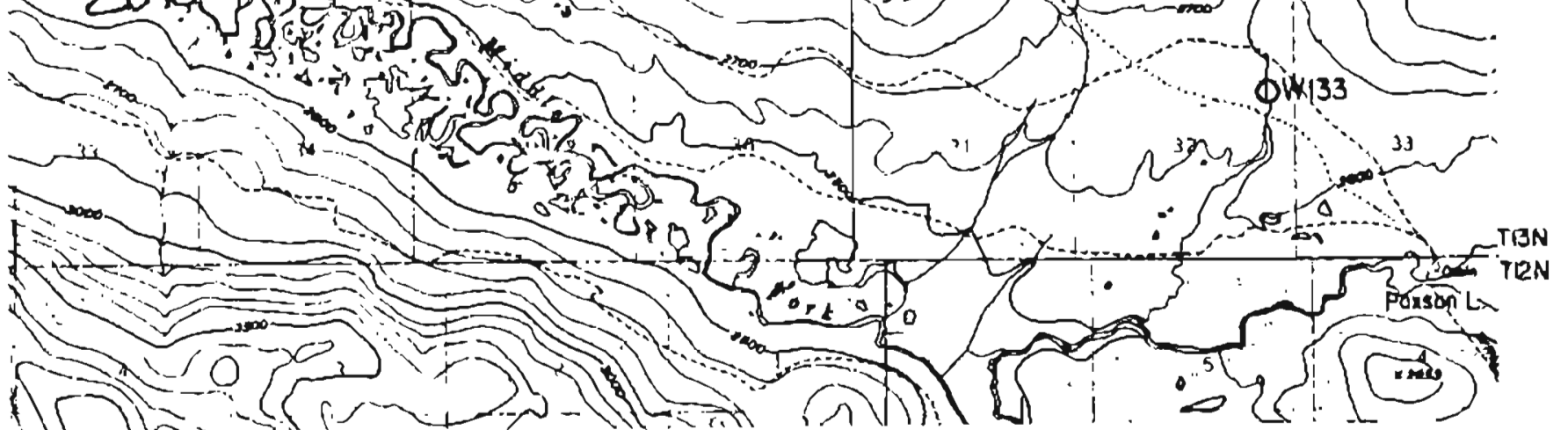

FLAT TOP MOUNTAIN AREA 
Flgure 6

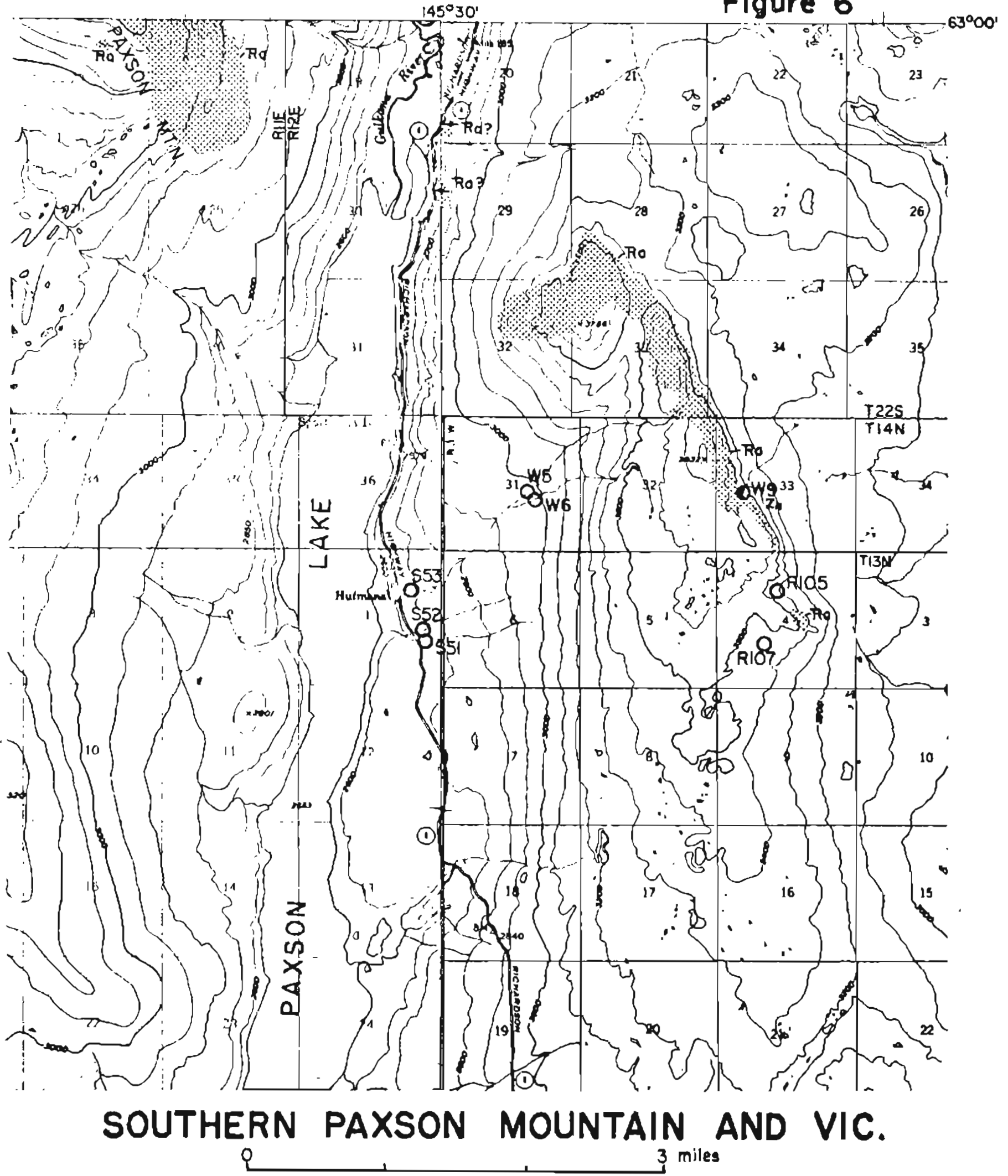




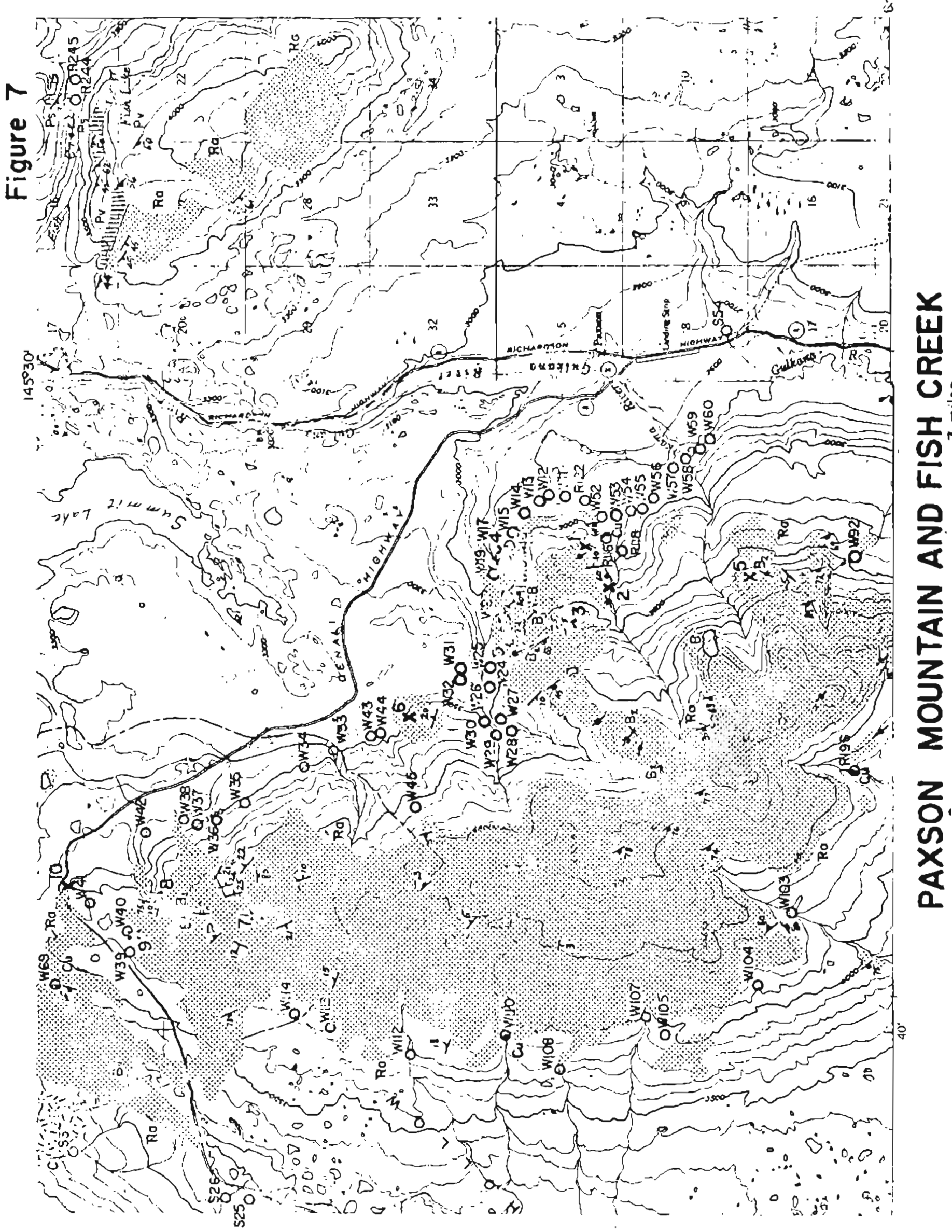




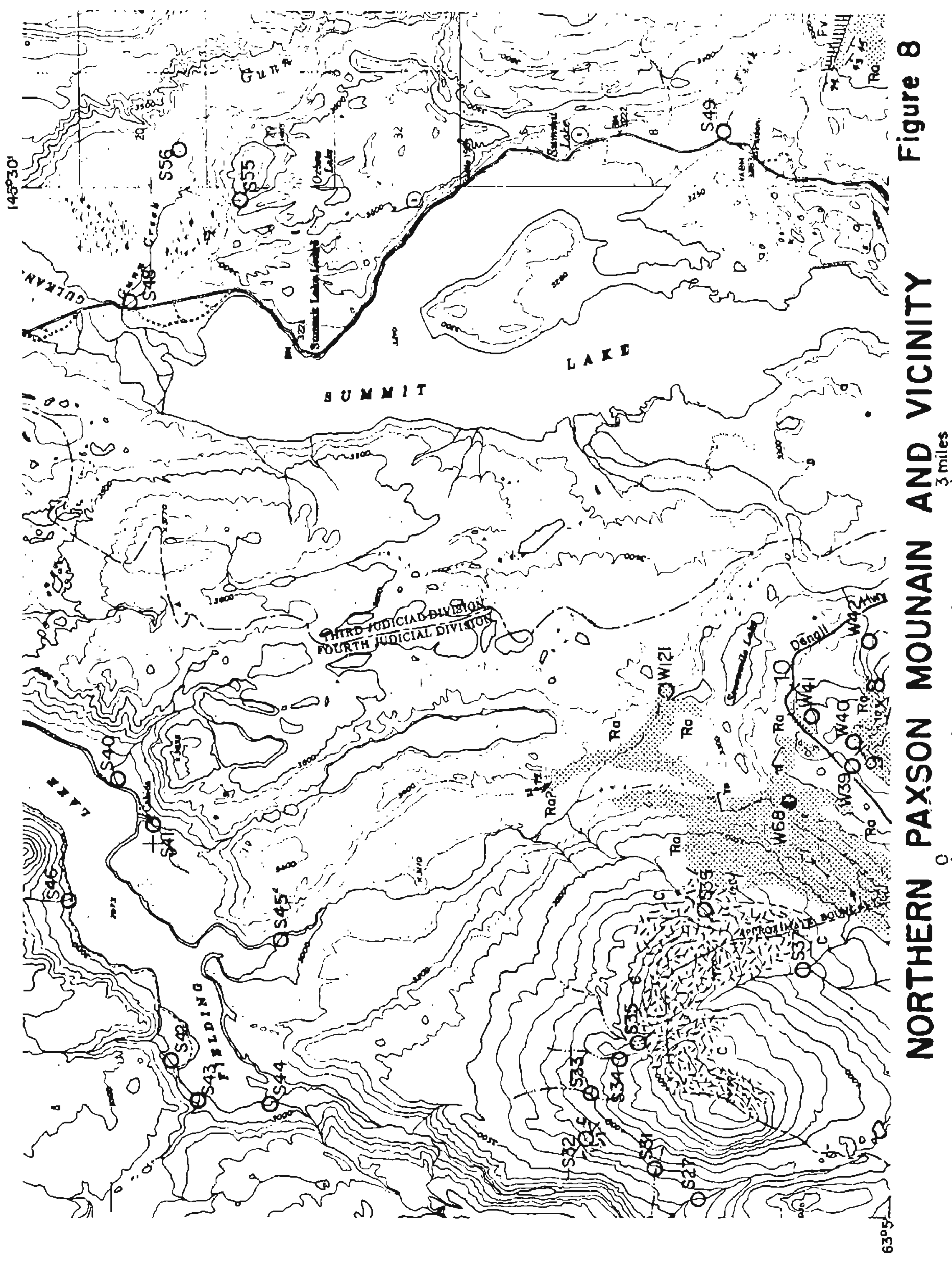




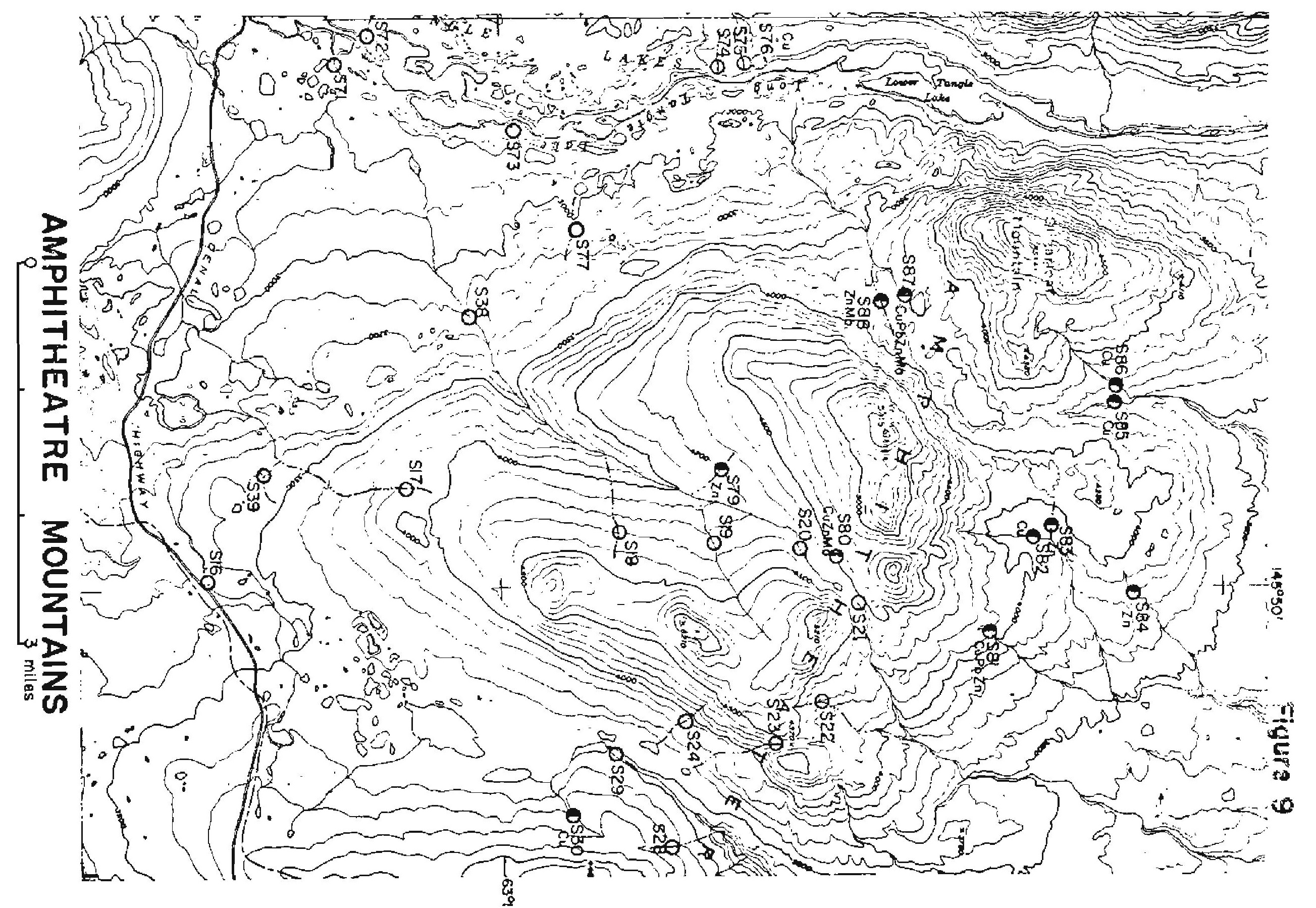




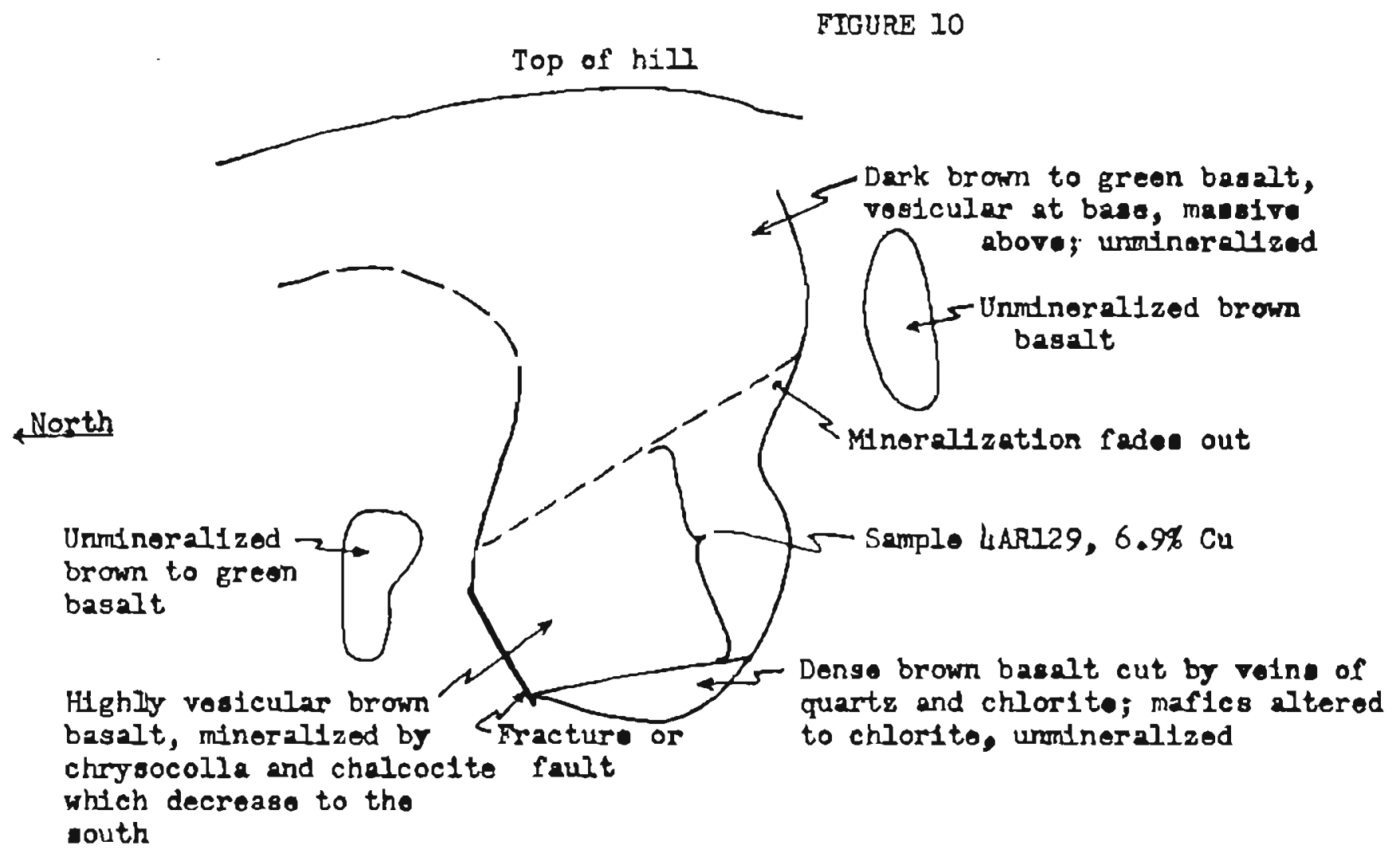

SKETCH OF HILISIDE AT LOCALTTY 3

$10 \mathrm{ft.}$
$\begin{gathered}\text { Approxdmate } \\ \text { scalo }\end{gathered}$
Looking egst 


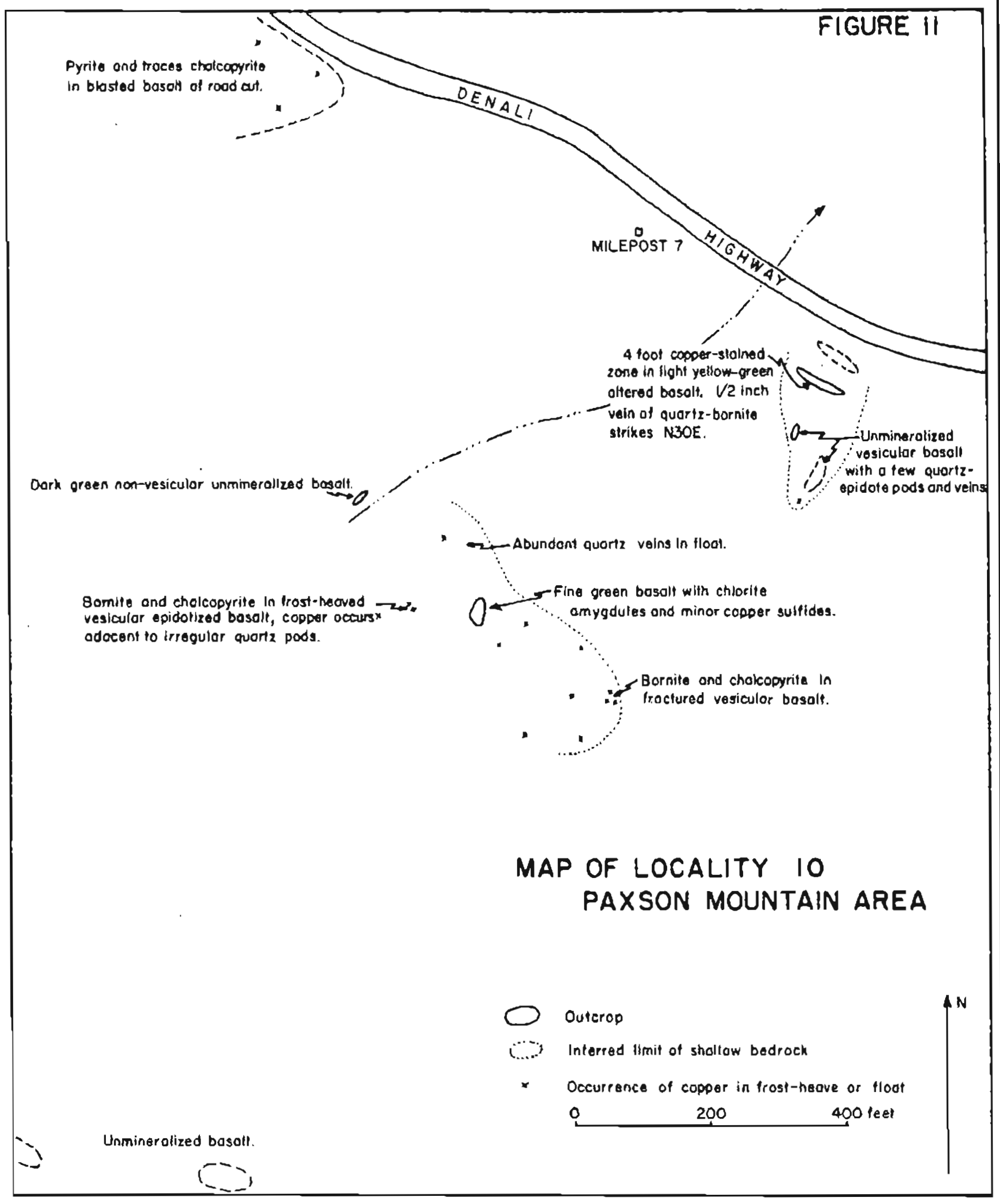

